8-2001

\title{
Sources and cycling of dissolved and particulate organic radiocarbon in the northwest Atlantic continental margin
}

JE Bauer

Virginia Institute of Marine Science

ERM Druffel

DM Wolgast

S Griffin

Follow this and additional works at: https://scholarworks.wm.edu/vimsarticles

Part of the Biogeochemistry Commons

\section{Recommended Citation}

Bauer, JE; Druffel, ERM; Wolgast, DM; and Griffin, S, Sources and cycling of dissolved and particulate organic radiocarbon in the northwest Atlantic continental margin (2001). Global Biogeochemical Cycles, 15(3), 615-636.

$10.1029 / 2000 G B 001314$

This Article is brought to you for free and open access by the Virginia Institute of Marine Science at W\&M ScholarWorks. It has been accepted for inclusion in VIMS Articles by an authorized administrator of W\&M ScholarWorks. For more information, please contact scholarworks@wm.edu. 


\title{
Sources and cycling of dissolved and particulate organic radiocarbon in the northwest Atlantic continental margin
}

\author{
James E. Bauer, ${ }^{1}$ Ellen R. M. Druffel, ${ }^{2}$ David M. Wolgast, ${ }^{3}$ and Sheila Griffin ${ }^{2}$
}

\begin{abstract}
Continental shelves and slopes are productive and dynamic ocean margin systems that also regulate the fluxes of terrestrial, riverine, and estuarine materials between the continents and oceans. In order to evaluate the ages, potential sources, and transformations of organic matter in an ocean margin system, we measured the radiocarbon $\left(\Delta^{14} \mathrm{C}\right)$ and $\delta^{13} \mathrm{C}$ distributions of total dissolved organic carbon (DOC), suspended particulate organic carbon (POC), and dissolved inorganic carbon (DIC) in waters of the Middle Atlantic Bight (MAB) continental shelf and slope in April-May 1994. The $\Delta^{14} \mathrm{C}$ of DOC was greatest (as high as -39\%o) in surface waters of the shelf, decreasing rapidly offshore and with depth, even in relatively shallow $(25-50 \mathrm{~m}$ depth) shelf waters. The lowest $\Delta^{14} \mathrm{C}$-DOC values were observed in deep slope waters, where they were significantly lower than values measured previously for the deep Sargasso Sea. There was a strong inverse relationship between $\Delta^{14} \mathrm{C}$-DOC and $8^{13} \mathrm{C}$-DOC in all shelf and surface slope waters of the $\mathrm{MAB}$, which is likely attributable to varying contributions of young, ${ }^{14} \mathrm{C}$-enriched organic matter of terrestrial and/or riverine origin. The more highly ${ }^{14} \mathrm{C}$-depleted DOC in deep slope waters (as low as $-442 \%$ ) generally had a correspondingly lower $\delta^{13} \mathrm{C}$ (as low as $-22.3 \%$ ) component. However, this must originate from relic terrestrial material either in the MAB itself or be discharged to the MAB from rivers and estuaries. The isotopic signatures of POC were clearly differentiable from DOC and indicate that this pool also contained a broad range of both old and young material of terrestrial $\left(\delta^{13} \mathrm{C}\right.$ as low as $\left.-24.9 \%\right)$ and marine $\left(\delta^{13} \mathrm{C}\right.$ as high as $\left.-19.9 \%\right)$ origin throughout the MAB shelf and slope. The highest $\Delta^{14} \mathrm{C}-\mathrm{POC}$ values (up to $78 \%$ ) were observed in shallow shelf waters of the southern MAB. Conversely, the lowest $\Delta^{14} \mathrm{C}-\mathrm{POC}$ values (as low as $-394 \%$ ) were found in MAB deep slope waters and were also significantly more depleted in ${ }^{14} \mathrm{C}$ than POC from the central north Atlantic (Sargasso Sea). A multiple-source isotopic mass balance model employing both ${ }^{14} \mathrm{C}$ and ${ }^{13} \mathrm{C}$ was used to evaluate the relative contributions of both young and old terrigenous versus marine organic matter to DOC and POC in the MAB. The results indicate that shelf and slope DOC is comprised of an old "marine" fraction (represented by offshore Sargasso Sea material) and either a young "terrestrial/riverine/ estuarine" (TRE) component (in shelf and shallow slope waters) or a relic TRE component (in deep and some shallow slope waters). In contrast, suspended POC from the MAB appears to originate predominantly from a mixture of recent MAB primary production and an old, TRE component, similar to that observed in one of the major subestuaries of the Chesapeake Bay. These results suggest that both young and old sources of terrestrial and riverine organic matter can comprise a significant fraction of the DOC and POC in ocean margins. Preliminary calculations indicate that the export of this compositionally unique DOC and suspended POC may be significant terms in the organic carbon budgets of the MAB and other margin systems.
\end{abstract}

\section{Introduction}

Ocean margins (continental shelf and slope systems) constitute $\sim 15-20 \%$ of the ocean's surface area, yet may account for up to half of the total oceanic primary production and new production [Eppley and Peterson, 1979; Eppley, 1989]. These coastal regions

\footnotetext{
${ }^{1}$ School of Marine Science, College of William and Mary, Gloucester Point, Virginia.

${ }^{2}$ Department of Earth System Science, University of California, Irvine, California.

${ }^{3}$ Marine Research Division, Scripps Institution of Oceanography, University of California, La Jolla, California.

Copyright 2001 by the American Geophysical Union.

Paper number $2000 \mathrm{~GB} 001314$.

0886-6236/01/2000GB001314\$12.00
}

are also important zones for the transport of terrestrial and riverine organic matter to the open ocean [Mantoura and Woodward, 1983; Mulholland and Watts, 1982; Moran et al., 1991; Hedges, 1992; Hedges et al., 1997; Kiel et al., 1997; J. E. Bauer, et al., Distribution, transport and fate of organic and inorganic radiocarbon in the Amazon River plume, submitted to Geochimica Et Cosmochimica Acta, 2001]. Primary production in margins (estimated at greater than $\sim 8 \times 10^{15} \mathrm{~g} \mathrm{C} \mathrm{yr}^{-1}$ globally [Valiela, 1995]), coupled with significant regional inputs of terrestrial organic matter by rivers $\left(\sim 0.40 \times 10^{15} \mathrm{~g} \mathrm{C} \mathrm{yr}^{-1}\right.$ for the sum of DOC and POC globally [Hedges et al., 1997]), make continental shelf and slope systems important and dynamic regions of carbon fixation, flux and transformation [Wollast, 1998].

Although they represent a relatively small portion of the total world ocean, margins have been hypothesized to serve as quantitatively important regions through which the respiration of the ocean's interior may be subsidized [Smith and MacKenzie, 
1987; Holland, 1995; Bauer and Druffel, 1998; del Giorgia et al., 1997]. The net autotrophic character of ocean margins [Smith and Hollibaugh, 1993; del Giorgia et al., 1997; Duarte and Agusti, 1998; Duarte et al., 1999] also indicates that they exhibit a slight excess of $\mathrm{CO}_{2}$ fixation versus heterotrophic organic matter respiration. Hence there is a net flux of inorganic to organic forms of carbon in these systems. It has also been hypothesized that some fraction of this surplus organic matter may be transported from the continental shelf and slope into the deep, interior ocean [Walsh, 1989, 1991; Smith and Hollibaugh, 1993; Bauer and Druffel, 1998].

One recent piece of evidence supporting this hypothesis is the existence of one or more "depocenters" [Anderson et al., 1994], or regions of high sedimentary organic carbon content, along the continental slope of the Middle Atlantic Bight (MAB). However, earlier findings from studies such as the California Basin Study [Small, 1992] and the Shelf Edge Exchange Program [Walsh et al., 1988; Biscaye et al., 1994] were equivocal with respect to the quantitative significance of fluxes from margins to the open ocean. For example, Falkowski et al. [1988] reported that less that $\sim 20 \%$ of the spring bloom in continental shelf waters was exported from the MAB to the North Atlantic Ocean in the form of particulate organic matter.

It is noteworthy that earlier studies of carbon export from ocean margins assumed fluxes of organic carbon from the ocean's margins to its interior take place predominantly in the form of particulate organic carbon (POC, typically measured as organic carbon collected by filtration of seawater on $\sim 0.7-\mu \mathrm{m}$ glass fiber filters) and mostly evaluated the larger sinking fraction of POC that was collected in sediment traps. The flux estimates from these earlier studies excluded contributions from dissolved organic carbon (DOC, or the organic carbon that passes through glass filters), which could be quantitatively significant. Apart from riverine [Richey et al., 1990; Spitzy and lttekot, 1991] and estuarine systems [Fisher et al., 1998] where contributions from DOC and suspended POC fluxes can be comparable, concentrations of dissolved organic carbon are $1-3$ orders of magnitude greater than POC concentrations in most marine systems [Williams and Druffel, 1987; Druffel et al., 1992, 1996; Bauer et al., 1998]. Therefore if the appropriate advective and eddy diffusive transports are of sufficient magnitudes, fluxes of DOC and suspended POC, particularly in the horizontal dimension [Jenkins, 1977; Hung et al., 1999], could be comparable to, if not greater than, sinking POC fluxes [Bauer and Druffel, 1998; Bianchi et al., 1998; Sherrell et al., 1998], by factors similar to the differences in horizontal versus vertical eddy diffusivity [Ledwell et al., 1993].

The MAB is one of the most intensively studied ocean margin systems in the world. The hydrographic [e.g., Houghton et al., 1994; Shaw et al., 1994; Churchill and Berger, 1998] and geochemical [e.g., Anderson et al., 1994; Guo et al., 1996; Bates and Hansell, 1999] complexity of the MAB make it a challenge to establish the qualitative and quantitative importance of organic matter both produced there, as well as imported to and exported from adjacent terrestrial/riverine and marine systems. The dominance of low-salinity, buoyant plume waters on the MAB shelf [Boicourt, 1981; Malone and Ducklow, 1990; Churchill and Berger, 1998; Bates and Hansell, 1999] suggests that there may be a significant contribution, and subsequent cycling, of organic matter derived from terrestrial, river, and estuarine systems that is transported to shelf and slope waters.

The predominant flow of shelf water in the MAB is from the northeast toward the southwest, and a significant component of the low-salinity shelf water is derived from an extensive coastal circulation system originating farther north in the Labrador Sea and Scotian Shelf regions [Mountain, 1991; Loder et al., 1998]. These source waters may consequently carry their own unique

Table 1. Locations, Depths, and Hydrographic Information for Stations Sampled for $\Delta^{14} \mathrm{C}$ and $\delta^{13} \mathrm{C}$ in the Middle Atlantic Bight, April 1994

\begin{tabular}{|c|c|c|c|c|c|c|}
\hline Transect & Station & $\begin{array}{c}\text { Station } \\
\text { Depth, } \mathrm{m}\end{array}$ & $\begin{array}{c}\text { Latitute/ } \\
\text { Longitude }\end{array}$ & $\begin{array}{l}\text { Sampling } \\
\text { Depth, } \mathrm{m}\end{array}$ & $\begin{array}{c}\text { Salinity, } \\
\text { psu }\end{array}$ & $\begin{array}{c}\text { Temperature, } \\
{ }^{\circ} \mathrm{C}\end{array}$ \\
\hline \multirow{3}{*}{3} & & & Northern & & & \\
\hline & 10 & 42 & $40^{\circ} 41.80^{\prime} \mathrm{N} /$ & 5 & 31.08 & 6.7 \\
\hline & & & $72^{\circ} 14.64^{\prime} \mathrm{W}$ & 25 & 32.57 & 3.6 \\
\hline \multirow[t]{2}{*}{3} & 12 & $\sim 65$ & $40^{\circ} 19.75^{\prime} \mathrm{N} /$ & 5 & 31.66 & 6.1 \\
\hline & & & $72^{\circ} 01.97^{\prime} \mathrm{W}$ & 50 & 33.24 & 4.1 \\
\hline \multirow[t]{4}{*}{3} & 16 & 1257 & $39^{\circ} 37.72^{\prime} \mathrm{N} /$ & 5 & 33.57 & 10.2 \\
\hline & & & $71^{\circ} 37.78^{\prime} \mathrm{W}$ & 300 & 35.29 & n.d. \\
\hline & & & & 750 & 35.09 & 4.6 \\
\hline & & & & 1000 & 35.09 & 4.1 \\
\hline \multirow[b]{2}{*}{6} & & & Central & & & \\
\hline & 40 & $\sim 18$ & $\begin{array}{l}37^{\circ} 38.13^{\prime} \mathrm{N} / \\
75^{\circ} 16.13^{\prime} \mathrm{W}\end{array}$ & 5 & 31.42 & 7.6 \\
\hline \multirow[t]{2}{*}{6} & 42 & 23 & $37^{\circ} 30.31^{\prime} \mathrm{N} /$ & 5 & 29.46 & 12.2 \\
\hline & & & $74^{\circ} 58.62^{\prime} \mathrm{W}$ & 15 & 31.91 & 9.0 \\
\hline \multirow{4}{*}{6} & 46 & 1558 & $37^{\circ} 11.54^{\prime} \mathrm{N} /$ & 5 & 31.29 & 10.7 \\
\hline & & & $74^{\circ} 16.91^{\prime} \mathrm{W}$ & 300 & 35.45 & 9.7 \\
\hline & & & & 750 & 35.09 & 4.8 \\
\hline & & & & 1000 & 35.31 & 4.2 \\
\hline \multirow[b]{2}{*}{8} & & & Southern & & & \\
\hline & 62 & 21 & $35^{\circ} 39.04^{\prime} \mathrm{N} /$ & 5 & 32.73 & 18.2 \\
\hline & & & $75^{\circ} 23.83^{\prime} \mathrm{W}$ & & & \\
\hline \multirow[t]{2}{*}{8} & 58 & 50 & $35^{\circ} 38.99^{\prime} \mathrm{N} /$ & 5 & 33.27 & 18.8 \\
\hline & & & $74^{\circ} 57.18^{\prime} \mathrm{W}$ & 40 & 35.72 & 17.8 \\
\hline \multirow[t]{4}{*}{8} & 55 & $\sim 1900$ & $35^{\circ} 39.06^{\prime} \mathrm{N} /$ & 5 & 36.16 & 22.5 \\
\hline & & & $74^{\circ} 36.78^{\prime} \mathrm{W}$ & 300 & 35.57 & 10.5 \\
\hline & & & & 750 & 35.14 & 4.8 \\
\hline & & & & 1000 & 35.09 & 4.2 \\
\hline
\end{tabular}




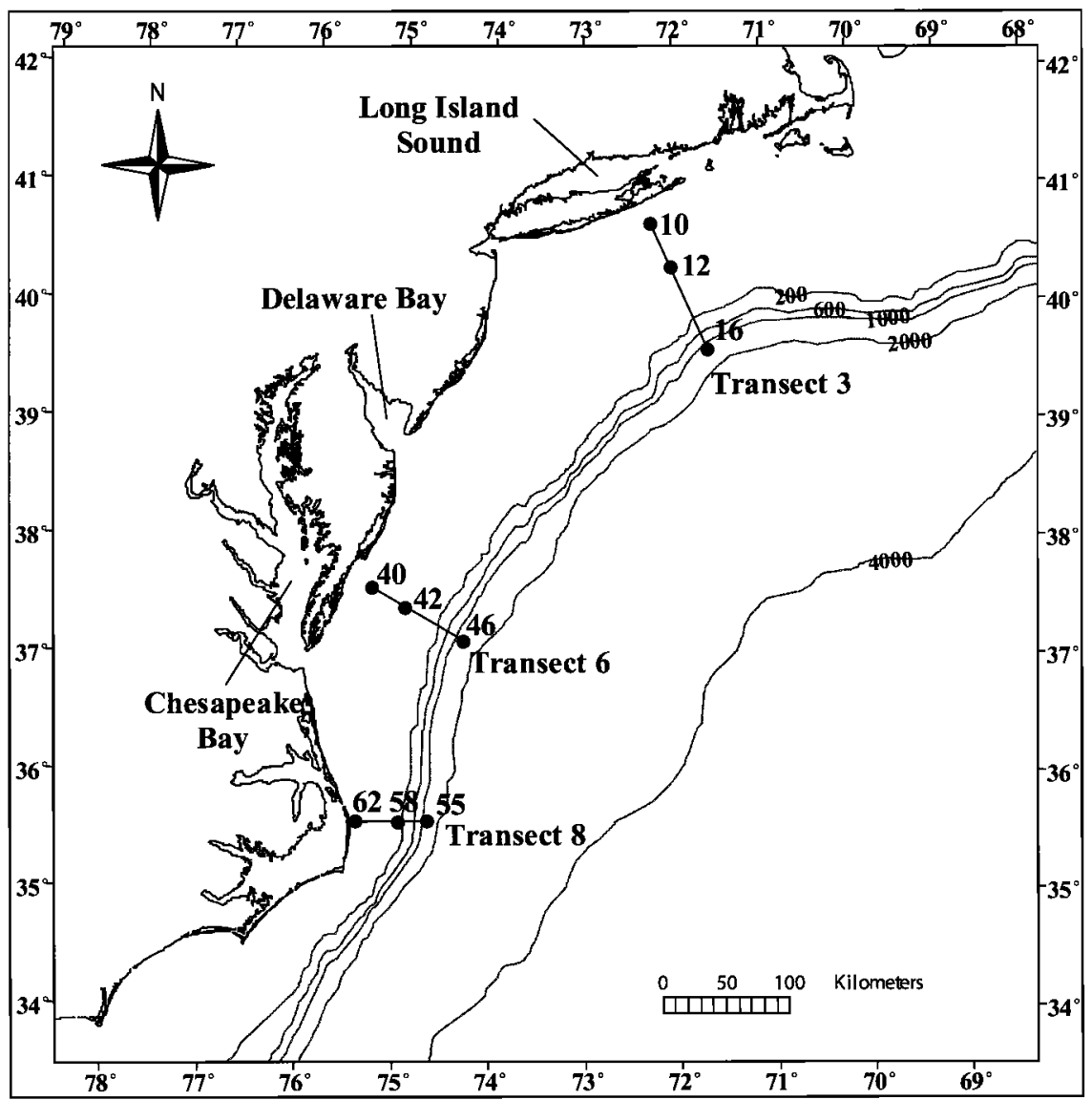

Figure 1. The Mid-Atlantic Bight, showing transects and stations sampled as part of this study. Depths at which samples were collected and seafloor depths at each station are given in Table 1.

organic isotopic signatures with them. Losses of water and materials from the MAB occur both along its length as well as via eastward offshore transport in the vicinity of Cape Hatteras [Churchill and Berger, 1998; Loder et al., 1998]. Both mechanisms may mediate the transfer of materials between the MAB, Gulf Stream, and open North Atlantic [Bates and Hansell, 1999].

In addition, the MAB has been found to contain dissolved inorganic carbon (DIC) with low $\Delta^{14} \mathrm{C}$ values that have been explained by the intrusion of Antarctic Intermediate Water (AAIW) into slope and shelf surface waters [Tanaka et al., 1990; Kashgarian and Tanaka, 1991]. The exact timing and cause of these intrusions is uncertain. However, the low $\Delta^{14} \mathrm{C}$ values have been hypothesized to result from upwelled AAIW onto the slope by deeper waters of the Gulf Stream. It has consequently been suggested that up to $40 \%$ of the water entering the MAB from the north may at times be composed of AAIW [Tanaka et al., 1990]. These excursions of $\Delta^{14} \mathrm{C}$ in the DIC pool of the MAB have also been hypothesized to result in the lower radiocarbon signatures of biologically fixed carbon there [Tanaka et al., 1990; Kashgarian and Tanaka, 1992]. Thus the $\Delta^{14} \mathrm{C}$ of surface mixed layer DIC may vary significantly on both a temporal and spatial basis [Kashgarian and Tanaka, 1992] and may consequently affect the $\Delta^{14} \mathrm{C}$ signatures of the various organic carbon pools found there.

A dual carbon isotopic approach was employed in the present study to establish the spatial distributions (both regionally and through the water column) of DOC and POC in the MAB as well as the relative source strengths and ages of organic matter in this region. Radiocarbon and stable carbon isotopic natural abundances in DOC, POC, and DIC were used to establish the relative contributions of variably aged allochthonous and autochthonous organic matter to the water column of the MAB shelf and slope. Although natural isotopic abundances may have a lower degree of specificity than organic biomarkers, they may be more suitable "integrators" of organic matter sources and ages and may be less influenced by those diagenetic factors that can alter the abundances and distributions of individual organic compounds. Natural ${ }^{14} \mathrm{C}$ and ${ }^{13} \mathrm{C}$ have been employed previously to examine organic matter dynamics in the MAB and associated waters [e.g., Guo et al., 1996; Mitra et al., 2000]. However, these earlier studies measured exclusively the high-molecular weight fraction of DOC $>1$ and $>10$ kDaltons, typically no more than $\sim 20-30 \%$ and $\sim 3-6 \%$, respectively, of the total DOC), which may or may not be representative of the total DOC pool. These studies were also limited to a small number of selected stations in the southernmost part of the MAB. The present study attempts to establish the concurrent sources, inventories, and radiocarbon-based residence times of total DOC and suspended POC within and across a major occan margin system.

\section{Materials and Methods}

\subsection{Study Location}

Three stations on each of three transects across the MAB shelf and slope between eastern Long Island and Cape Hatteras were sampled for carbon isotopic characterization of DOC, POC, and 
DIC between April 18 and May 1, 1994, on the R/V Columbus Iselin (Table 1 and Figure 1). Transects were carried out at a generally perpendicular orientation to the major isobaths. These transects were chosen in order to provide broad geographic coverage, to evaluate potential carbon inputs (i.e., from Chesapeake and Delaware Bays), and to establish the ranges in isotopic signatures for each of the carbon pools within the MAB.

The three transects chosen for study of carbon isotopic distributions (Figure 1) were (1) transect 3, located off the eastern end of Long Island (away from the influence of the Chesapeake and Delaware Bays), (2) transect 6, between Chesapeake and Delaware Bays, and (3) transect 8, off Cape Hatteras. On each transect, samples in shelf waters were collected from surface $(5 \mathrm{~m})$ and, wherever possible, near-bottom depths (Table 1). In slope waters, samples were collected from four depths $(5,300,750$, and 1000 $\mathrm{m})$. Each of the slope stations was at a different lateral distance from the shelf-slope break, and as a result the $1000 \mathrm{~m}$ samples were at different heights above the seafloor (Table 1). Salinities were strongly influenced by the proximity of stations to the major freshwater inputs to the MAB. Surface ( $5 \mathrm{~m}$ depth) salinities were lowest in inshore and midshelf waters and increased in the offshore slope stations. The highest salinity (36.16 psu; Table 1) was observed at station 55, where the influence of Gulf Stream waters was apparent. Deep (300-1000 m) slope waters (stations 16, 46, and 55) averaged $35.24 \pm 0.18$ psu salinity. Surface and shelf water temperatures (Table 1) generally increased from north to south and from onshore to offshore, and a strong vertical temperature gradient was often observed even in shallow shelf waters. A full treatment of the hydrographic data obtained during this cruise as well as more comprehensive coverage of DOC concentrations made along all eight transects are presented by $\mathrm{P}$. Vlahos et al. (Fluxes of dissolved organic carbon (DOC) in the Mid-Atlantic Bight, submitted to Deep Sea Research, Part II, 2001).

\subsection{Sample Collection}

Precleaned (using methanol, dilute $\mathrm{HCl}$, and double distilled water) 12 and $30 \mathrm{~L} \mathrm{Go-flo} \mathrm{bottles} \mathrm{were} \mathrm{used} \mathrm{to} \mathrm{collect} \mathrm{water} \mathrm{for}$ $\Delta^{14} \mathrm{C}$ of DOC, suspended POC, DIC, and for total $\mathrm{CO}_{2}$, alkalinity, and salinity. One liter water samples for DOC analyses were filtered directly from Go-flo bottles through baked $\left(450^{\circ} \mathrm{C}\right.$ for 4 hours) $143 \mathrm{~mm}$ diameter Whatman quartz fiber filters (QFF; 0.8 $\mu \mathrm{m}$ nominal pore size) and frozen at $-20^{\circ} \mathrm{C}$ immediately after collection. Suspended POC was considered to be that fraction that was collected directly on the QFF filters. The POC sample filters were frozen immediately at $-20^{\circ} \mathrm{C}$ in prebaked glass jars. The filtered water samples for $\Delta^{14} \mathrm{C}$ of DIC $(500 \mathrm{~mL}), \mathrm{TCO}_{2}(250 \mathrm{~mL})$, and alkalinity $(250 \mathrm{~mL})$ were poisoned with $100 \mu \mathrm{L}$ of a saturated $\mathrm{HgCl}_{2}$ solution and stored at room temperature. All storage bottles and other materials (filters, forceps, etc.) contacting the samples were precombusted at $525^{\circ} \mathrm{C}$ for 4 hours and stored in baked aluminum foil and air-tight plastic bags prior to use.

\subsection{Dissolved Organic Carbon}

Concentrations, $\Delta^{14} \mathrm{C}$ and $\delta^{13} \mathrm{C}$ of DOC were determined by high-energy UV irradiation ( $2400 \mathrm{~W}$ ) of $650 \mathrm{~mL}$ seawater samples [Bauer et al., 1992a, 1992b, 1998]. Samples were acidified to $\mathrm{pH}$ 2.5 with phosphoric acid and sparged with ultra-high purity nitrogen gas for $30 \mathrm{~min}$. to remove inorganic carbon, saturated with ultra-high purity oxygen gas, and irradiated with a medium pressure mercury arc UV lamp (Canrad-Hanovia, Newark, New Jersey) for 2 hours. The $\mathrm{CO}_{2}$ generated from DOC oxidation was purified and collected on a vacuum extraction line. Concentrations of DOC were determined using a calibrated Baratron absolute pressure gauge (MKS Industries) to measure $\mathrm{CO}_{2}$ pressure on the vacuum line. Following quantification, the sample was split approximately 10:1 into two break-seal tubes, with the larger

Table 2. Concentrations, $\Delta^{14} \mathrm{C}$, and $\delta^{13} \mathrm{C}$ Isotopic Compositions, and Equivalent Ages of DOC, POC, and DIC From the Middle Atlantic Bight, April 1994

\begin{tabular}{|c|c|c|c|c|c|c|c|c|c|c|c|c|c|c|}
\hline \multirow[b]{2}{*}{ Transect } & \multirow[b]{2}{*}{$\begin{array}{c}\text { Station } \\
\text { Number }\end{array}$} & \multirow[b]{2}{*}{$\begin{array}{c}\text { Depth, } \\
\text { m }\end{array}$} & \multicolumn{4}{|c|}{$\mathrm{DOC}$} & \multicolumn{4}{|c|}{ POC } & \multicolumn{4}{|c|}{ DIC } \\
\hline & & & $\begin{array}{c}\text { DOC } \\
\mu M\end{array}$ & $\begin{array}{r}{ }^{14} \mathrm{C}, \\
\% \\
\end{array}$ & $\begin{array}{c}\text { Age, } \\
\text { yr BP }\end{array}$ & $\begin{array}{c}\delta^{13} \mathrm{C} \\
\% 0\end{array}$ & $\begin{array}{l}\text { POC } \\
\mu \mathrm{g} \mathrm{L}^{-1}\end{array}$ & $\begin{array}{c}{ }^{14} \mathrm{C}, \\
\% 0\end{array}$ & $\begin{array}{l}\text { Age, } \\
\text { yr BP }\end{array}$ & $\begin{array}{c}\delta^{13} \mathrm{C} \\
\% 0\end{array}$ & $\begin{array}{c}\mathrm{DIC} \\
\mu \mathrm{mol} \mathrm{kg}^{-1}\end{array}$ & $\begin{array}{c}{ }^{14} \mathrm{C} \\
\%\end{array}$ & $\begin{array}{l}\text { Age, } \\
\text { yr BP }\end{array}$ & $\begin{array}{c}\delta^{13} \mathrm{C}, \\
\% 0\end{array}$ \\
\hline \multicolumn{15}{|c|}{ Northern } \\
\hline 3 & 10 & 5 & 102 & -186 & 1653 & -22.9 & 103 & 15 & $\operatorname{Mod}^{\mathrm{a}}$ & -22.4 & 1938 & 56 & Mod & 1.4 \\
\hline 3 & 10 & 25 & 81 & -207 & 1863 & -21.9 & 138 & 22 & Mod & -23.6 & 2083 & 60 & Mod & 0.5 \\
\hline 3 & 12 & 5 & 88 & -160 & 1401 & nd & 76 & 25 & Mod & -23.0 & 1965 & 60 & Mod & 1.0 \\
\hline 3 & 12 & 50 & 69 & -211 & 1904 & -22.2 & 38 & 49 & Mod & -21.3 & 2077 & 48 & Mod & 0.9 \\
\hline 3 & 16 & 5 & 77 & -234 & 2141 & -21.9 & 148 & 51 & Mod & -22.4 & 2030 & 46 & Mod & 1.6 \\
\hline 3 & 16 & 300 & 46 & -433 & 4558 & -21.9 & 6.7 & -57 & 471 & nd & 2188 & -28 & 228 & 0.7 \\
\hline 3 & 16 & 750 & 47 & -418 & 4348 & -21.6 & 3.6 & nd & nd & -23.7 & 2164 & -31 & 253 & 1.0 \\
\hline 3 & 16 & 1000 & 47 & -442 & 4686 & -21.7 & 3.7 & nd & nd & nd & 2159 & -29 & 236 & 1.0 \\
\hline \multicolumn{15}{|c|}{ Central } \\
\hline 6 & 40 & 5 & 99 & -92 & 775 & -22.6 & 190 & -16 & 130 & -24.0 & 1981 & nd & nd & nd \\
\hline 6 & 42 & 5 & 115 & -39 & 320 & -22.7 & nd & nd & nd & nd & 1880 & 53 & Mod & 1.8 \\
\hline 6 & 42 & 15 & 89 & -76 & 635 & -22.3 & 143 & 15 & Mod & -24.3 & 1973 & 31 & Mod & 1.6 \\
\hline 6 & 46 & 5 & 91 & -107 & 909 & -22.1 & 131 & 31 & Mod & -24.5 & 1981 & 48 & Mod & 0.4 \\
\hline 6 & 46 & 300 & 53 & -403 & 4144 & -21.5 & 9.4 & -73 & 609 & -24.9 & 2171 & -24 & 195 & 1.0 \\
\hline 6 & 46 & 750 & 52 & -451 & 4817 & -21.4 & 3.7 & 31 & Mod & -23.1 & 2170 & -27 & 220 & 1.1 \\
\hline 6 & 46 & 1000 & 51 & -408 & 4211 & -21.3 & 5.7 & -146 & 1268 & -24.1 & 2175 & -42 & 345 & 1.1 \\
\hline \multicolumn{15}{|c|}{ Southern } \\
\hline 8 & 62 & 5 & 112 & -98 & 829 & -22.8 & 186 & 78 & Mod & -20.4 & 1937 & 76 & Mod & 0.9 \\
\hline 8 & 58 & 5 & 111 & -145 & 1258 & -22.7 & 139 & 66 & Mod & -19.9 & 2113 & 44 & Mod & 0.9 \\
\hline 8 & 58 & 40 & 69 & -272 & 2550 & -22.0 & 315 & -45 & 370 & -21.4 & 1929 & 62 & Mod & 1.5 \\
\hline 8 & 55 & 5 & 83 & -306 & 2934 & -22.4 & 45 & -44 & 361 & -22.9 & 2024 & 79 & Mod & 1.5 \\
\hline 8 & 55 & 300 & 53 & -428 & 4487 & -22.3 & 4.0 & -171 & 1506 & nd & 2166 & -2 & 16 & 0.8 \\
\hline 8 & 55 & 750 & 50 & -438 & 4629 & -22.0 & 2.7 & nd & nd & nd & 2165 & nd & nd & nd \\
\hline 8 & 55 & 1000 & 50 & -438 & 4629 & -22.2 & 3.2 & -394 & 4024 & $\mathrm{nd}$ & 2161 & -51 & 420 & nd \\
\hline
\end{tabular}

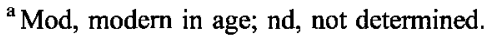



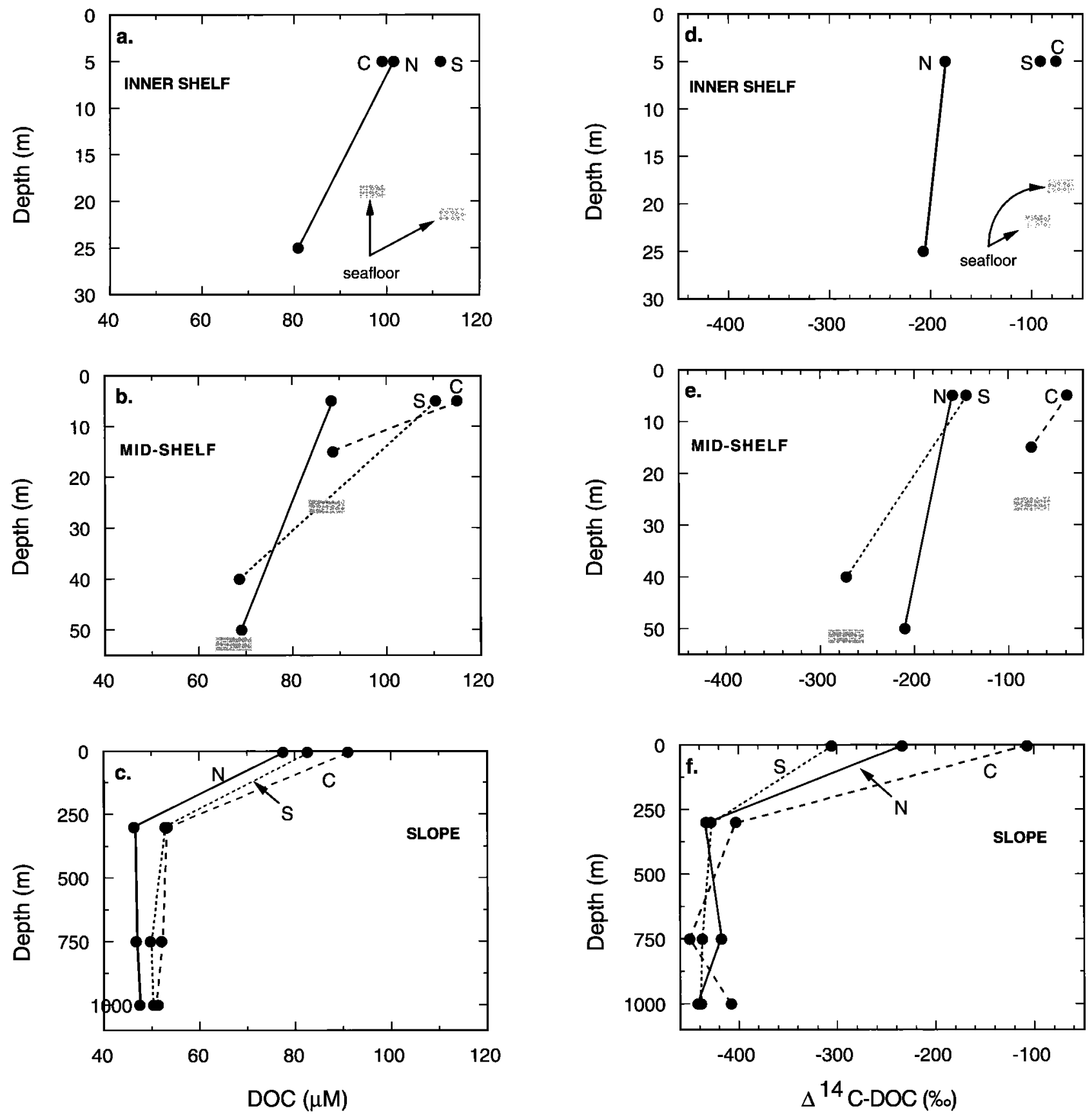

Figure 2. Inner shelf, midshelf, and slope distributions of (a)-(c) DOC concentrations, (d) $-(f) \Delta^{14} \mathrm{C}$ of DOC, and (g)-(i) $\delta^{13} \mathrm{C}$ of DOC as determined by high-energy UV oxidation of large volume samples from the Mid-Atlantic Bight. Stippled pattern in Figures $2 a$ and $2 b$ indicates approximate seafloor depth at central (C) and southern (S) transect stations on the inner and middle shelf. Seafloor depths for all stations are given in Table 1. Note changes in depth scales.

portion being used for $\Delta^{14} \mathrm{C}$ analysis and the smaller portion being used for $\delta^{13} \mathrm{C}$ analysis. DOC concentrations were also measured by discrete injection high-temperature catalytic oxidation (HTCO) using aluminosilicate and Pt-impregnated catalysts [Bauer et al., 1993; Williams et al., 1993]. All HTCO determinations of DOC were corrected by appropriate system blanks using methods suggested both by Hedges et al. [1993] and Peltzer [1994]. In addition, both blank water and seawater samples have been measured in conjunction with recent laboratory intercalibrations [Sharp et al., 1993]. Measuring DOC concentrations by these two independent methods (i.e., high-energy UV oxidation and discreteinjection HTCO) also served as a cross check of potential measurement artifacts that could otherwise lead to inaccurate concentration values.

\subsection{Suspended POC and DIC}

The concentrations, $\Delta^{14} \mathrm{C}$, and $\delta^{13} \mathrm{C}$ values of suspended POC were measured from the same sample collections as DOC (see section 2.3). The material collected on the quartz fiber filters was 

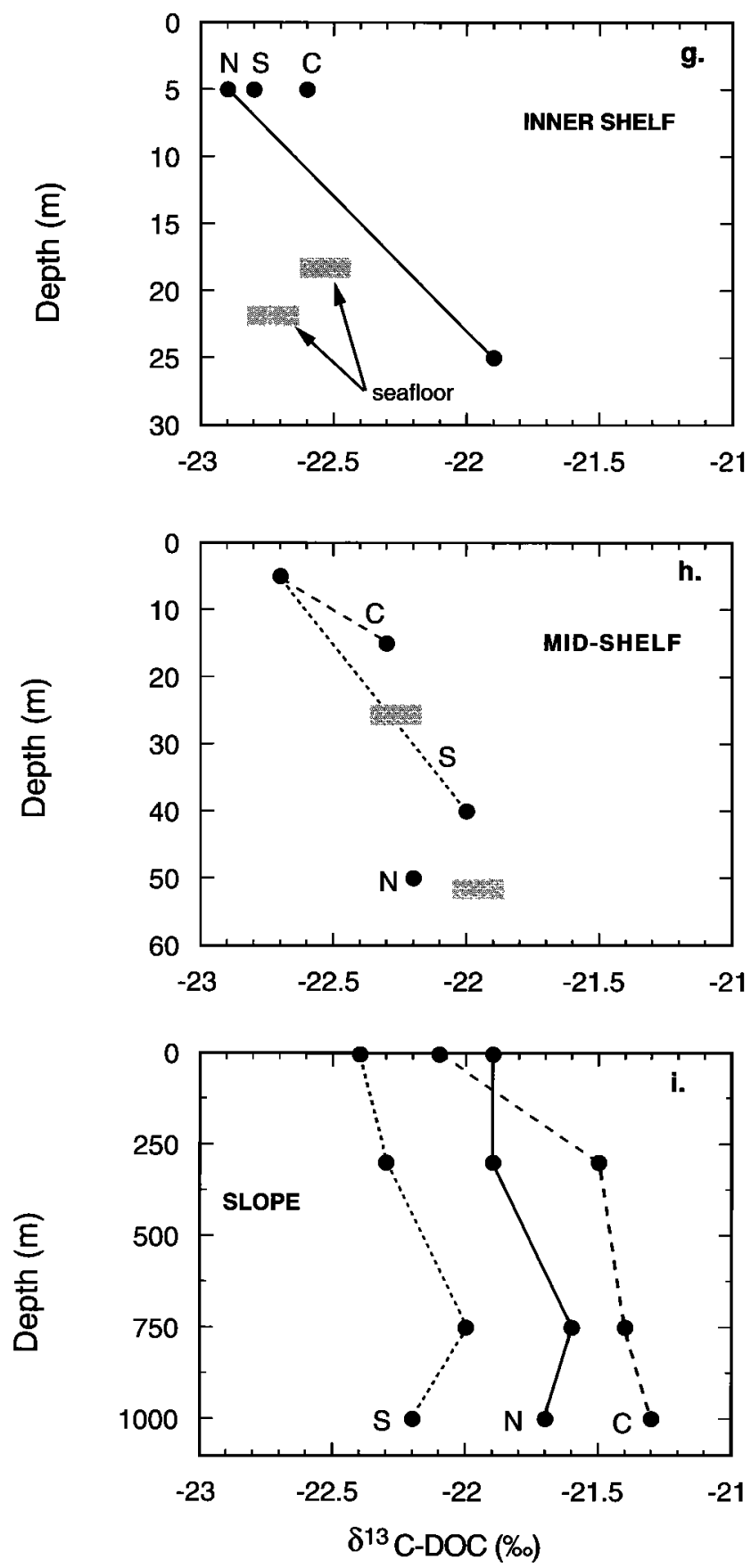

Figure 2. (continued)

acidified overnight with $1 \% \mathrm{H}_{3} \mathrm{PO}_{4}$ to remove carbonates, dried in vacuo, and the $\mathrm{POC}$ oxidized to $\mathrm{CO}_{2}$ by dry combustion with $\mathrm{CuO}$ and $\mathrm{Ag}$ metal at $850^{\circ} \mathrm{C}$ in double quartz tubes [Sofer, 1980; Druffel et al., 1992]. Yields of $\mathrm{CO}_{2}$ were quantified using an absolute pressure gauge on a vacuum extraction line, and aliquots were taken for $\Delta^{14} \mathrm{C}\left(\sim 90 \%\right.$ of the total) and $\delta^{13} \mathrm{C}(\sim 10 \%$ of the total) measurements. Samples for $\Delta^{14} \mathrm{C}$ and $\delta^{13} \mathrm{C}$ analysis of DIC (250 $\mathrm{mL}$ ) were acidified using $85 \% \mathrm{H}_{3} \mathrm{PO}_{4}$. The sample was sparged using ultra-high purity $\mathrm{N}_{2}$ gas, and the evolved $\mathrm{CO}_{2}$ was collected cryogenically and purified on a vacuum extraction line, and the sample was split as above for $\Delta^{14} \mathrm{C}$ and $\delta^{13} \mathrm{C}[$ McNichol et al., 1994].

\subsection{Isotopic Analyses}

The $\Delta^{14} \mathrm{C}$ analyses of the small amounts of carbon $(\sim 50-500 \mu \mathrm{g}$ C) recovered from these procedures were performed by accelerator mass spectrometry (AMS) at the Center for AMS at Lawrence Livermore National Laboratory (LLNL). The $\mathrm{CO}_{2}$ derived from all samples was converted to graphite in an atmosphere of $\mathrm{H}_{2}$ over Co catalyst [Vogel et al., 1987]. Total measurement uncertainties for $\Delta^{14} \mathrm{C}$ analyses of these samples were typically $\pm 5-10 \%$. The $\delta^{13} \mathrm{C}$ measurements of $\mathrm{DOC}_{u v}$ were made using a Finnegan Delta $\mathrm{S}$ isotope ratio mass spectrometer with an analytical precision better than $0.1 \%$, while those for suspended POC and DIC were made using a Micromass $602 \mathrm{E}$ unit (also with an analytical precision of $0.1 \%$ ).

\section{Results}

The specific goals of this study were (1) to evaluate potential source terms and residence times for DOC and POC of continental shelf and slope waters of the MAB, (2) to evaluate the isotopic composition of DOC relative to that of the POC and DIC, (3) to assess potential regional sources of organic matter to DOC and POC in the MAB, and (4) to compare the isotopic composition and turnover times of MAB shelf and slope DOC and POC to that of the interior North Atlantic (Sargasso Sea). The results of all DOC, POC, and DIC concentration, $\Delta^{14} \mathrm{C}$ and $\delta^{13} \mathrm{C}$ analyses are shown in Table 2.

\subsection{Dissolved Organic Carbon}

DOC concentrations, as determined by high-energy UV oxidation of large volume $(650 \mathrm{~mL})$ samples, decreased from shallow MAB shelf to surface slope waters and with depth in slope waters (Table 2; Figures $2 \mathrm{a}-2 \mathrm{c}$ ). Surface water $(5 \mathrm{~m})$ distributions of DOC (Table 2) showed that concentrations of DOC were generally higher onshore and along the low-salinity central MAB transect. In shelf waters, large decreases in DOC concentrations were noted over small depth intervals (Figures $2 a$ and $2 b$ ), and the deeper samples invariably corresponded with significantly higher salinity (Tables 1 and 2). Of the three slope stations (Figure 2c), station 46 of central $\mathrm{MAB}$ transect 6 showed the highest DOC concentrations, while northern transect 3 had the lowest concentrations.

The $\Delta^{14} \mathrm{C}$ values of DOC in the MAB also exhibited spatial differences as a function of both station location and depth (Figure $2 \mathrm{~d}-2 \mathrm{f}$ ). The most highly ${ }^{14} \mathrm{C}$-enriched values were found in lower salinity surface waters of the central and southern inner and middle shelf (Figures $2 \mathrm{~d}$ and $2 \mathrm{c}$ ). The average radiocarbon ages of this ${ }^{14} \mathrm{C}$-enriched DOC ranged from $\sim 500$ to 700 years B.P. and are among the youngest ages reported anywhere for seawater total DOC. The DOC from all deeper, higher salinity shelf waters was lower in $\Delta^{14} \mathrm{C}$ (Figures $2 \mathrm{~d}$ and $2 \mathrm{e}$ ). Deep MAB slope waters contained the lowest $\Delta^{14} \mathrm{C}$-DOC values (Figure 2f), and resembled $\Delta^{14} \mathrm{C}$ signatures observed previously for deep open ocean regions [Bauer et al., 1992a, 1992b; Druffel et al., 1992]. It is noteworthy that midshelf and surface slope waters from central transect 6 were significantly enriched in ${ }^{14} \mathrm{C}$ compared to the other transects (Figures 2e and 2f). Deep slope waters of the central and southern transects were also significantly enriched relative to the northern transect (Figure 2f). This is especially interesting when we consider that the corresponding $\delta^{13} \mathrm{C}$ values of central transect 6 slope water samples were higher relative to slope waters to the north and south (see next paragraph and Figure 2i). The $\Delta^{14} \mathrm{C}-\mathrm{DOC}$ value in southern transect 8 surface $(5 \mathrm{~m})$ slope waters (station 55 ) is the lowest value $(-306 \%)$ ever observed for surface water DOC. The correspondingly high salinity (36.16 psu) in these surface waters indicates that this region of the MAB is strongly influenced by Gulf Stream waters [Bates and Hansell, 1999]. 

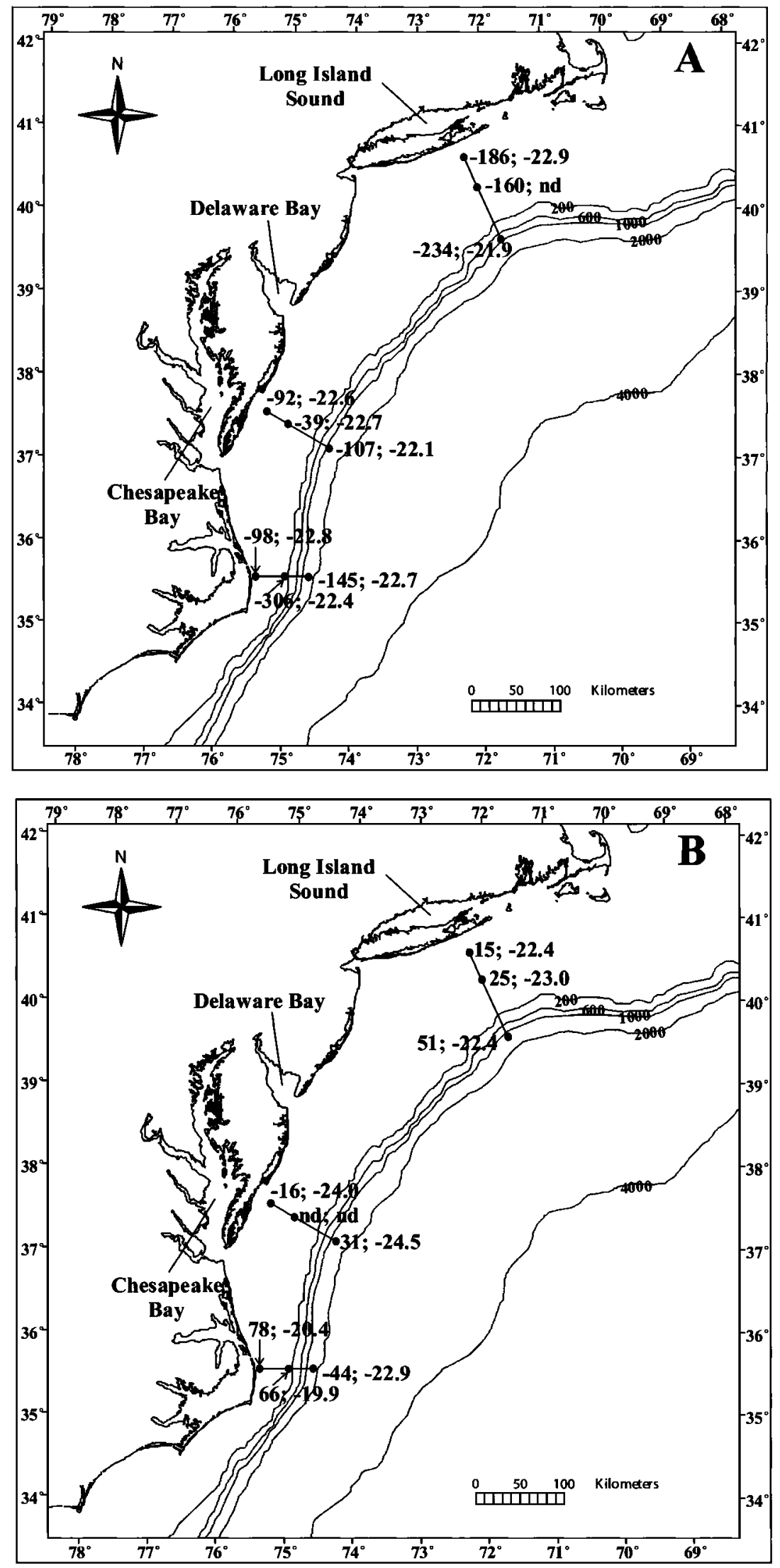

Figure 3. Surface (5 m depth) distributions of (a) $\Delta^{14} \mathrm{C}$ and $\delta^{13} \mathrm{C}$ of DOC and (b) $\Delta^{14} \mathrm{C}$ and $8^{13} \mathrm{C}$ of POC for transects and stations sampled in the Middle Atlantic Bight. Sequence of values for each station is as follows: left value, $\Delta^{14} \mathrm{C}$; right value, $\delta^{13} \mathrm{C}$; nd, not determined. 

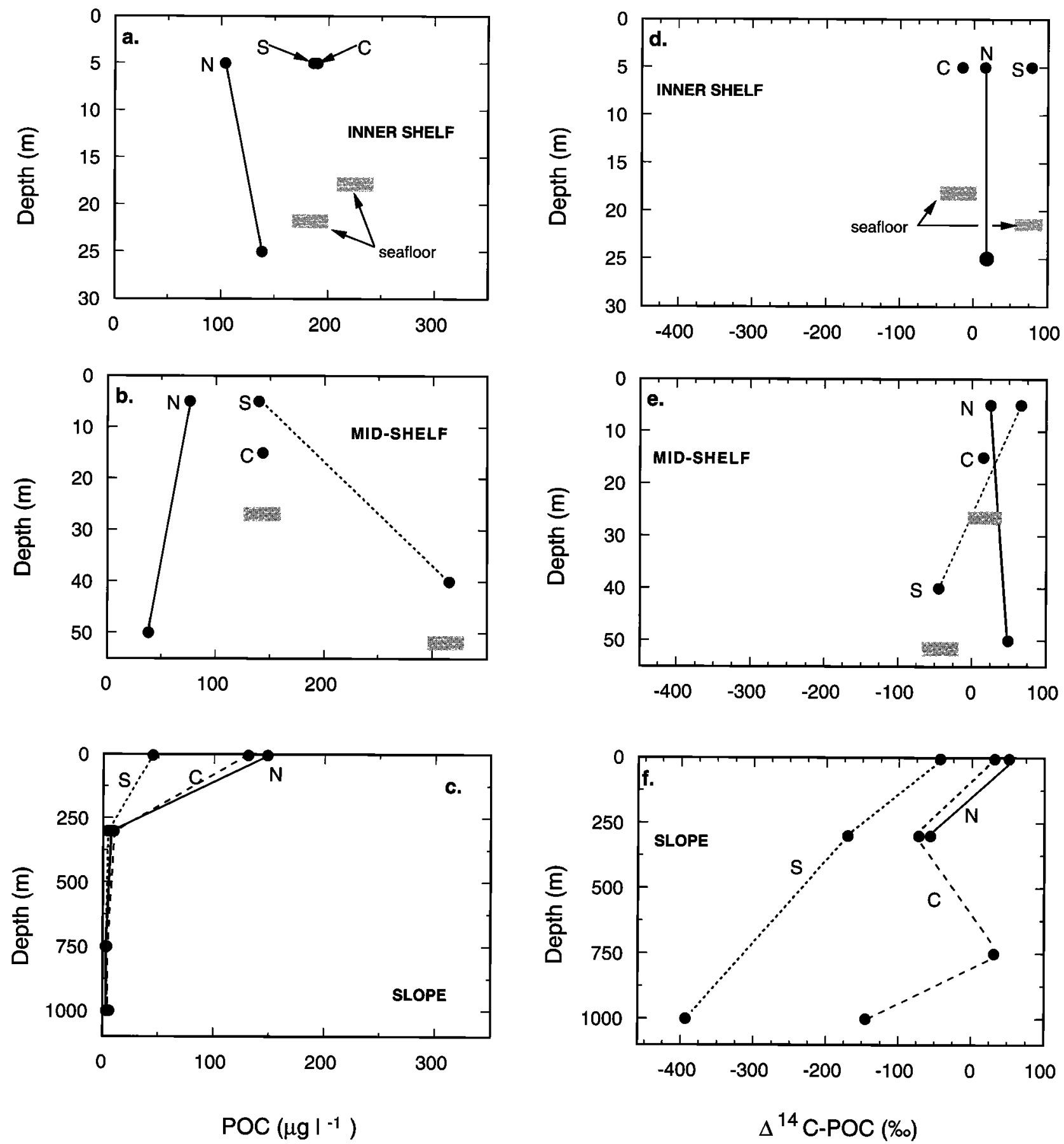

Figure 4. Inner shelf, midshelf, and slope distributions of (a) - (c) suspended POC concentrations, (d) $-(f) \Delta^{14} C$ of POC, and (g)-(i) $\delta^{13} \mathrm{C}$ of POC for samples from the Mid-Atlantic Bight. Stippled pattern in Figures $4 \mathrm{a}$ and $4 \mathrm{~b}$ indicates approximate seafloor depth at central (C) and southern (S) stations on the inner and middle shelf. Seafloor depths for all stations are given in Table 1 . Note changes in depth scales.

The magnitude and distribution of $\delta^{13} \mathrm{C}$ values of DOC in MAB waters (Figures $2 \mathrm{~g}-2 \mathrm{i}$ ) indicate that isotopically lighter, ${ }^{13} \mathrm{C}$ depleted organic matter persists in several regions of the shelf. Values of $\delta^{13} \mathrm{C}-\mathrm{DOC}$ in shallow, lower salinity shelf waters were invariably lower than deeper shelf waters (Figures $2 \mathrm{~g}$ and $2 \mathrm{~h}$ ), yet indicate a contribution of only $\sim 5-10 \%$ terrestrial material to shelf waters assuming that the $\delta^{13} \mathrm{C}$ end-members of terrestrial $\mathrm{C}_{3}$ plant material is approximately $-28 \%$ and marine DOC is approximately $-21 \%$. There was also a noticeable presence and/or persistence of DOC with a greater terrestrial $\delta^{13} \mathrm{C}$ contribution in slope waters of southern transect 8 near the Cape Hatteras region (Figure 2i). Moreover, there was clear separation of $\delta^{13} \mathrm{C}$ signatures 

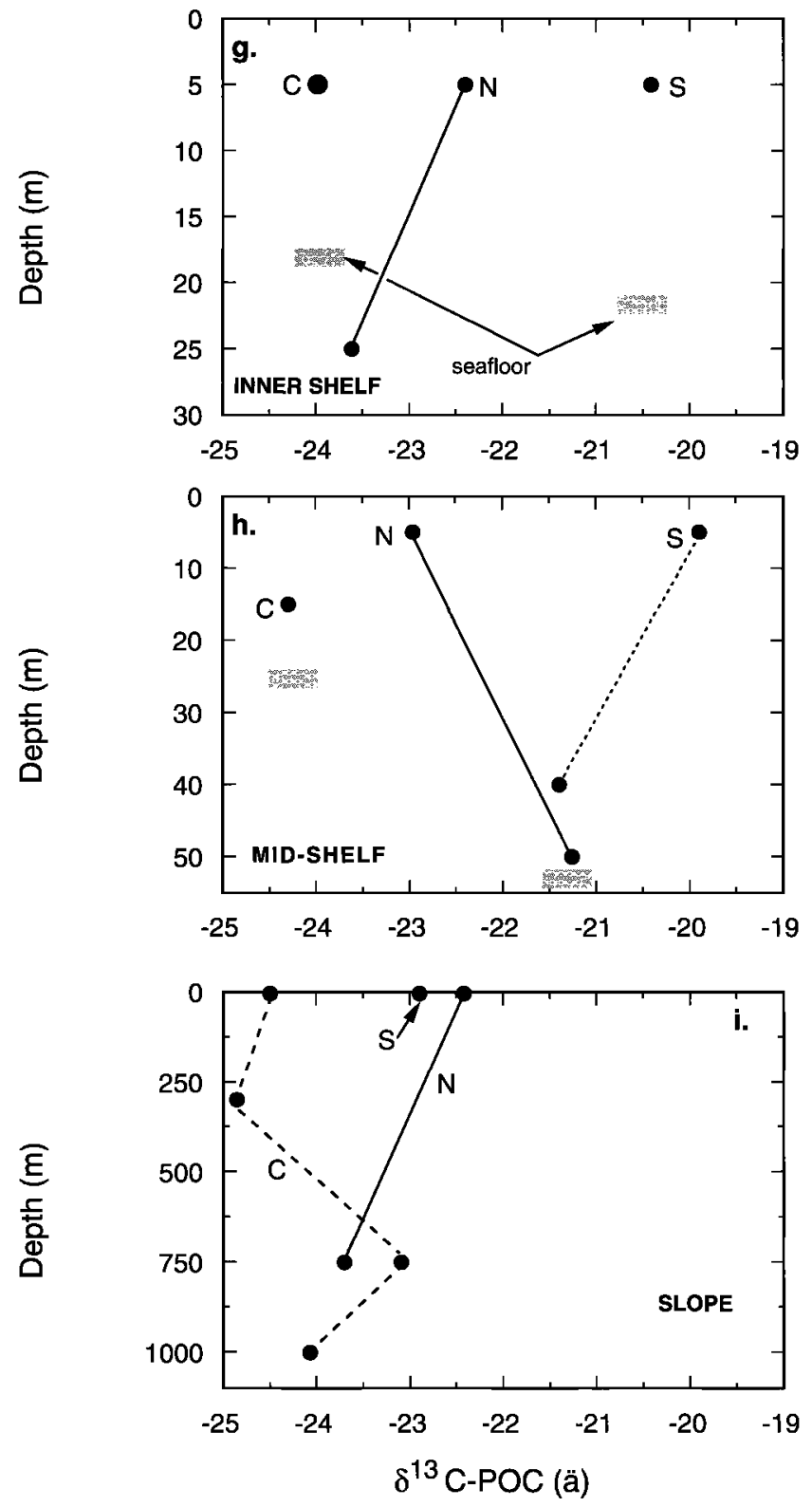

Figure 4. (continued)

of DOC through the water column between all slope stations (with the exception of central transect surface waters (Figure 2i), and the values were consistently higher in waters of the central slope and lowest in southern slope waters. This finding is intriguing in light of the corresponding $\Delta^{14} \mathrm{C}$ values for DOC in these same samples (Figure 2f; also, see section 4).

The highest surface DOC concentration (central transect midshelf station 42) corresponded with the highest $\Delta^{14} \mathrm{C}$ and one of the lowest $\delta^{13} \mathrm{C}$ values of the entire survey (Table 2). In addition, shallow $\Delta^{14} \mathrm{C}$-DOC values generally increased from slope to shelf waters, while $\delta^{13} \mathrm{C}$ of DOC in surface waters generally showed an opposing trend to $\Delta^{14} \mathrm{C}$ (Figure 3a). As a whole, these data indicate an increasing contribution and possible accumulation of ${ }^{14} \mathrm{C}$-enriched DOC of terrestrial and/or riverine origin both nearer to shore and in the region of the central shelf transect that also extends farther offshore. As we shall see in section 4 , however, we also cannot rule out possible contributions from relic terrestrial sources in the southern part of the MAB.

\subsection{Suspended Particulate Organic Carbon}

Concentrations of suspended POC in inner shelf and midshelf waters from northern transect 3 were lower by nearly a factor of 2 than concentrations in the central (6) or southern (8) transects (Table 2 and Figures $4 \mathrm{a}$ and $4 \mathrm{~b}$ ). At the southern slope sites, concentrations of POC ranged from 3 to $45 \mu \mathrm{g} \mathrm{L}^{-1}$, whereas at the central and north sites they ranged from 4 to $148 \mu \mathrm{g} \mathrm{L}^{-1}$ (Figure $4 \mathrm{c}$ ).

Suspended POC $\Delta^{14} \mathrm{C}$ and $\delta^{13} \mathrm{C}$ values for MAB shelf and slope waters are presented in Table 2 and Figures $4 d-4 i$. All of the inner shelf and midshelf samples contained significant quantities of bomb ${ }^{14} \mathrm{C}$ (i.e., $\Delta^{14} \mathrm{C}>$ about $-70 \%$ ). In the inner shelf and midshelf samples, surface $\Delta^{14} \mathrm{C}$ values were highest in waters from the southern transect and lowest in water from the central transect (Figures $4 \mathrm{~d}$ and $4 \mathrm{e}$ ).

The $\Delta^{14} \mathrm{C}$ values for POC from the slope stations (Figure $4 f$ ) were distinct from those of shelf waters (Figures $4 d$ and $4 \mathrm{f}$ ). First, the southern slope station (station 55) contained the lowest $\Delta^{14} \mathrm{C}$ POC values of all three stations. The $\Delta^{14} \mathrm{C}$-DOC results showed that values for the southern transect, while lower than those for the central slope, were essentially identical to the northern slope samples (Figure 2f). The $\Delta^{14} \mathrm{C}$-POC value at $1000 \mathrm{~m}$ depth at the southern slope station $(-394 \%)$ is to our knowledge the lowest suspended seawater POC value recorded in this or in any other study. Second, the surface POC $\Delta^{14} \mathrm{C}$ value at the southern transect was lower than the other two stations (Figure 4f), unlike the situation at the inner shelf and midshelf regions (Figures $3 \mathrm{~d}$ and $3 \mathrm{e}$ ), where the southern site had the highest $\Delta^{14} \mathrm{C}$ of the three sites.

The $\delta^{13} \mathrm{C}$ values of suspended POC varied from $-24.8 \%$ at 300 $\mathrm{m}$ depth at the slope site in the central transect to $-19.9 \%$ at $5 \mathrm{~m}$ depth in the middle of the southern transect (Table 2 and Figures $4 \mathrm{~g}-4 \mathrm{i})$. In general, $\delta^{13} \mathrm{C}-\mathrm{POC}$ values along the central transect were lower than for those from either the northern or the southern transect, and the $\delta^{13} \mathrm{C}$-POC values as a whole were much lower than the $\delta^{13} \mathrm{C}-\mathrm{DOC}$ values (Figures $2 \mathrm{~g}-2 \mathrm{i}$ ), in this part of the $\mathrm{MAB}$. This contrasts with what is typically observed in most open ocean settings (with the exception of polar regions), where the $\delta^{13} \mathrm{C}$ of DOC is typically $1-2 \%$ lighter than POC [Druffel et al., 1992; Druffel et al., 1996; Bauer et al., 1998]. It is also interesting to note that the $\delta^{13} \mathrm{C}$ values of POC from the slope station of the central transect (Station 46) are the lowest of the three slope stations (Figure 4i), and coincide with the high $\Delta^{14} \mathrm{C}$ values for both DOC (Figure 2f) and POC (Figure 4f) at this site. These data indicate collectively that this region (i.e., the central $\mathrm{MAB}$ ) is influenced significantly by relatively high ${ }^{14} \mathrm{C}$, low ${ }^{13} \mathrm{C}$ terrestrial organic matter, delivered via rivers and estuaries.

The surface $(5 \mathrm{~m})$ distributions of suspended POC concentration (Table 2), and $\Delta^{14} \mathrm{C}$ and $\delta^{13} \mathrm{C}$ (Figure $3 \mathrm{~b}$ ) did not show the same cross-shelf and along-shelf patterns as DOC (Table 2 and Figure 3a). In general, surface $\Delta^{14} \mathrm{C}-\mathrm{POC}$ was greatest at the inshore southern transect stations, but farther offshore on this transect surface values were the lowest of all surface waters in this study. The $\delta^{13} \mathrm{C}-\mathrm{POC}$ values were lowest in the surface waters of the central transect, followed by the northern and southern transects.

\subsection{Dissolved Inorganic Carbon}

All DIC $\Delta^{14} \mathrm{C}$ values from stations on the inner shelf and midshelf regions (Table 2 and Figures $5 \mathrm{a}$ and $5 \mathrm{~b}$ ) were greater than $-70 \%$, indicating the presence of bomb- ${ }^{14} \mathrm{C}$ and hence exchange with atmospheric $\mathrm{CO}_{2}$ since the late $1950 \mathrm{~s}$. On the slope (Table 2 and Figure $5 \mathrm{c}$ ), $\Delta^{14} \mathrm{C}$ values ranged from $-50 \%$ at 1000 $\mathrm{m}$ to $80 \%$ at the surface and also showed clear evidence of the bomb ${ }^{14} \mathrm{C}$ signature at all depths. The slope site (station 55) from the southern transect revealed the highest $\Delta^{14} \mathrm{C}$ value $(80 \%)$ at $5 \mathrm{~m}$ 

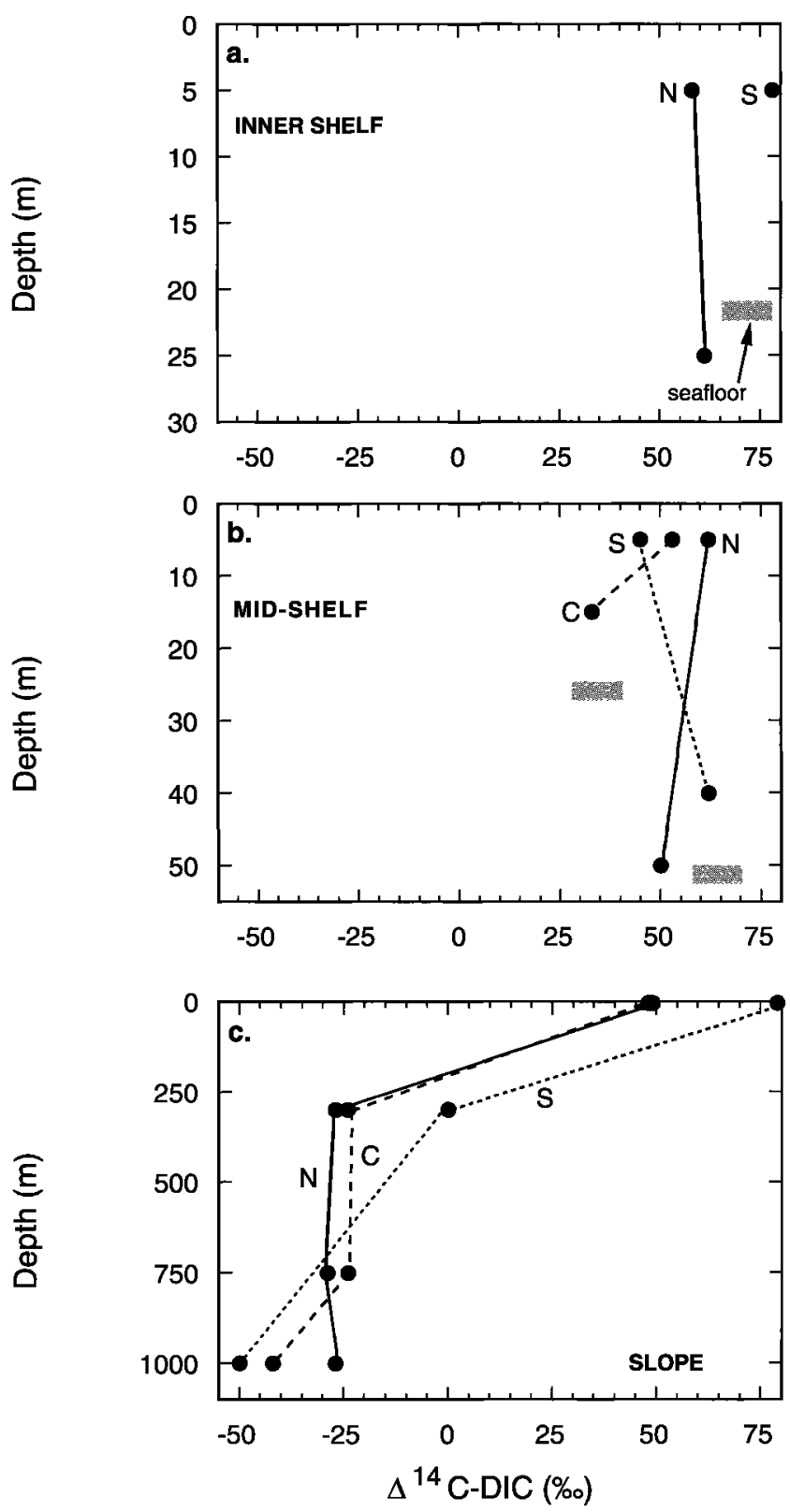

Figure 5. Profiles of $\Delta^{14} \mathrm{C}$ of DIC for stations from the (a) inner shelf, (b) middle shelf, and (c) slope of the MAB. Stippled pattern in Figures $5 \mathrm{a}$ and $5 \mathrm{~b}$ indicates approximate seafloor depth at central (C) and southern (S) transect stations on the inner and middle shelf. Seafloor depths for all stations are given in Table 1. Note changes in depth scales for each panel.

depth, as would be expected from intrusion of surface Gulf Stream waters, which originate in part from recirculated Sargasso Sea water [Iselin, 1936]. It is interesting to note that this same sample had the correspondingly lowest DOC $\Delta^{14} \mathrm{C}$ value $(-306 \%$; Table 2) of all surface samples in our survey of MAB waters. These $\Delta^{14} \mathrm{C}$ values for DIC compare favorably with those obtained from previous studies of the North Atlantic during the late 1980s [Ostlund and Rooth, 1990; Druffel et al., 1992]. However, the rapid decrease in $\Delta^{14} \mathrm{C}$ of DIC between 5 and $300 \mathrm{~m}$ indicates the presence of different water masses and little vertical exchange between surface and intermediate and deep slope waters.

\section{Discussion}

Waters of the MAB shelf and slope exhibit a broad range of DOC and POC radiocarbon and stable carbon isotopic signatures. The data presented in this study as a whole suggest the following three major observations: (1) the presence of relatively high $\Delta^{14} \mathrm{C}$ DOC and POC in lower salinity, buoyant shelf waters, (2) very low $\Delta^{14} \mathrm{C}$-DOC and POC in all deep and some surface slope waters, and (3) a variable terrestrial or riverine component (i.e., on the basis of $\delta^{13} \mathrm{C}$ values) in both the $\mathrm{DOC}$ and POC pools that was more strongly discernible in POC. In addition, the often anomalous nature of DOC concentrations and carbon isotopic values in the $\mathrm{MAB}$ indicates that there is a source (or multiple sources) of ${ }^{14} \mathrm{C}$ depleted organic matter to at least some (e.g., the southern) parts of this shelf-slope system. Below, we examine some of the regional as well as transect and site specific differences in the isotopic signatures of DOC and POC and attempt to place these findings in context with other available information on MAB carbon reservoirs, as well as those of the contiguous Chesapeake Bay and Sargasso Sea.

\subsection{Distributions and Isotopic Compositions of DOC and POC}

The concentrations of DOC measured in shelf and shallow slope waters (69-115 $\mu M$; Table 2 and Figures $2 a-2 c)$ using highenergy UV oxidation are within the ranges previously reported by other investigators using high-temperature catalytic oxidation methods for different parts of the MAB. Chen et al. [1996] observed concentrations of 72-85 $\mu M$ in shallow George's Bank waters, while in March 1996, Vlahos et al. [1998] found a much broader range of $\sim 60-140 \mu M$ throughout the entire MAB. The latter study observed increasing concentrations both onshore and southwestward toward Cape Hatteras. Guo et al. [1996] and Bates and Hansell [1999] also measured relatively high surface concentrations $(\sim 80-100 \mu M)$ in the southern part of the MAB near Cape Hatteras. Deeper slope waters $(300-1000 \mathrm{~m})$ in the present study had significantly lower concentrations (46-53 $\mu M$; Table 2 and Figure 2a) than surface waters. Concentrations in deep slope waters varied little with depth but were notably lower at northern slope station 16 than at the central (station 46) and southern (station 55) slope stations. The concentrations in our slope waters were virtually identical to concentrations $(47-56 \mu M)$ reported previously for deep slope waters in various regions of the MAB [Chen et al., 1996; Guo et al., 1996; Hopkinson et al., 1997].

The degree of conservative versus nonconservative behavior of a solute is typically established with respect to salinity. Although the salinity range covered in the present study was relatively narrow ( $29.5-36.2 \mathrm{psu}$; Table 1$)$, there was a strong inverse linear relationship $\left(y=-11.7 x+463 ; r^{2}=0.966 ; n=18\right)$ between DOC concentration and salinity, with the notable exception of samples from shallow waters of transect 8 (Figure 6a). Thus, excluding these four southern MAB samples, DOC exhibits at least quasi-conservative behavior during mixing of low-salinity shelf waters and high-salinity slope and Gulf Stream waters. One of the major implications of this observation is that within the constraint of the mean residence times of MAB waters (estimated at $\sim 100$ days for MAB shelf waters [Mountain, 1991]), DOC from the various terrestrial, riverine, estuarine, and other margin sources is not utilized significantly by microheterotrophic populations in this margin, at this time of year. While conservative behavior has been observed previously for DOC in regions of estuarine mixing [e.g., Mantoura and Woodward, 1983], this is the first evidence of shelf "end-member" material persisting into higher salinity regions of a shelf-slope system. This apparent conservative behavior of DOC in much of the MAB may result in part from the cold temperatures of shelf and slope waters during this time of year (March). As observed by Raymond and Bauer 
[2000], much of the normally labile terrestrial and riverine DOC carried by subestuaries of the Chesapeake Bay system is utilized at negligible rates during the coldest months but may subsequently become available for bacterial utilization as water temperatures rise.

The DOC from shallow depths at stations 55, 58, and 62 from southern transect 8 clearly shows significant departures from the

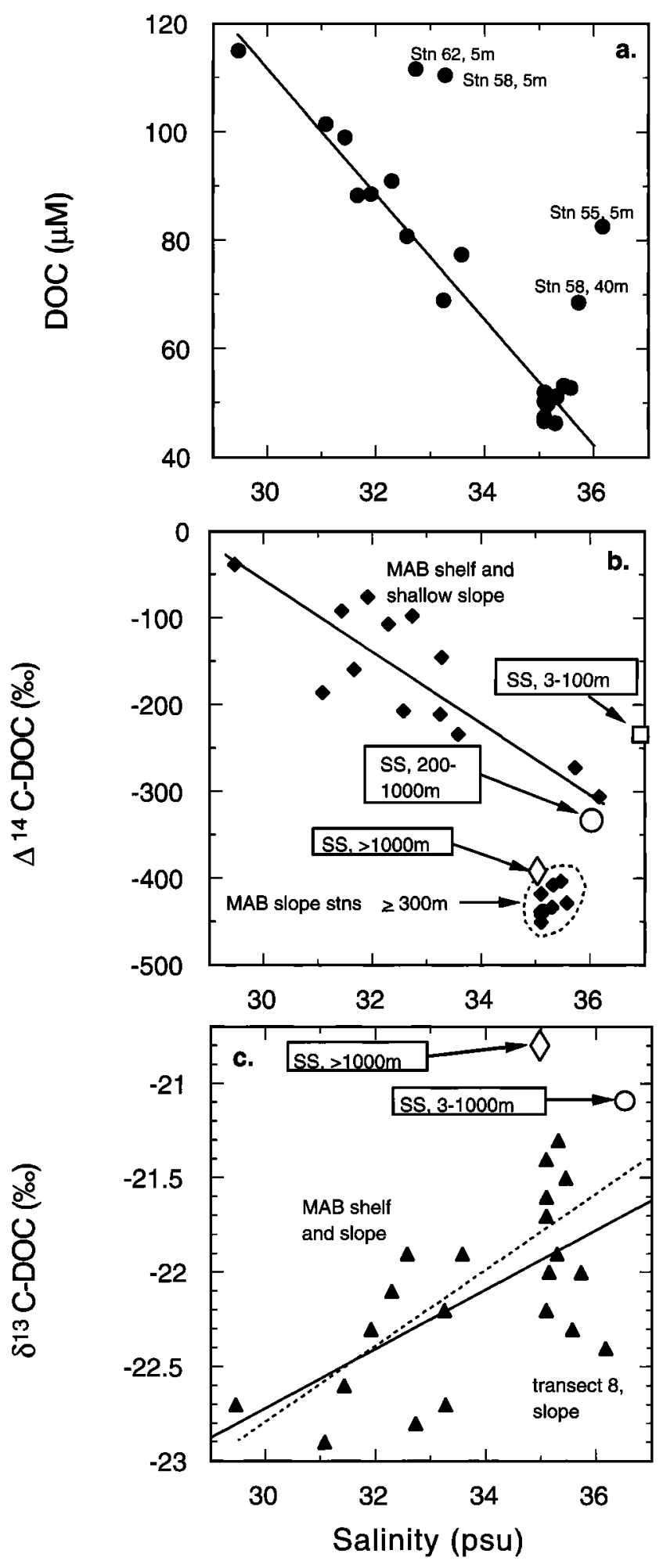

conservative relationship, and the DOC concentrations at these sites are indicative of one or more sources of DOC to the water column of this region. These sources may include exchanges with shelf and slope sediments and pore waters [Guo et al., 1996; Alperin et al., 1999; Burdige et al., 1999], submarine hydrocarbon seeps [Boehm and Requejo, 1986; M. Scranton, personal communication, 2000], atmospheric inputs [Chesselet et al., 1981; Zafiriou et al., 1985; Gagosian and Peltzer, 1986; Velinsky et al., 1986; Willey et al., 2000], desorbed DOC from sediment resuspension in this dynamic region [Meade et al., 1975; Nittrouer and Wright, 1994; Hedges and Keil, 1999], or "surplus" DOC derived from shelf and slope primary production in the vicinity of transect 8 [Bates and Hansell, 1999]. As we show below, these potential sources may be constrained by the $\Delta^{14} \mathrm{C}$ and $\delta^{13} \mathrm{C}$ data.

The $\Delta^{14} \mathrm{C}$-DOC versus salinity relationship for all samples showed a clear delineation between shelf and shallow slope waters and deeper slope waters (Figure 6b). Salinity explained approximately two-thirds of the variance in $\Delta^{14} \mathrm{C}-\mathrm{DOC}$ in shelf and shallow slope waters, with a range in $\Delta^{14} \mathrm{C}$-DOC of $(>270 \%$ over a concomitant salinity range of 6.7 psu $\left(y=-36.7 x+1034 ; r^{2}=\right.$ $0.686 ; n=13)$. The lowest salinity shelf water sample (29.16 psu) contained detectable bomb- $-{ }^{14} \mathrm{C}$, most likely of terrestrial origin, though sources of bomb- ${ }^{14} \mathrm{C}$ enriched shelf and estuarine organic matter cannot be ruled out entirely. Surface $(3 \mathrm{~m})$ Sargasso Sea waters averaged $-238 \%$ for $\Delta^{14} \mathrm{C}-\mathrm{DOC}$ [Bauer et al., 1992a, $1992 \mathrm{~b}$ ], which is lower than all but two (both from the southern transect) of the MAB shelf and shallow slope values (Table 2). It is also interesting to note that while DOC concentrations from the four southern $\mathrm{MAB}$ shallow samples indicated a strong source in this region, the $\Delta^{14} \mathrm{C}$ values for these samples were not notably anomalous, indicating that the age of this source of DOC is similar to the existing background DOC (Figure 6b). Deep (300-1000 m) slope waters exhibited a much narrower range in $\Delta^{14} \mathrm{C}-\mathrm{DOC}$ values ( -442 to $-418 \%$ ) over a salinity range of $35.1-35.6 \mathrm{psu}$ (Table 2 and Figure 6b). The influence of buoyant, low-salinity plumes on coastal circulation (see review by Hickey [2000]), sediment transport and deposition [Wright and Nittrouer, 1995], and planktonic food-web structure and function [Malone and Ducklow, 1990] has been studied in detail in a number of systems. The present study extends the influence of such plumes to include identifiable inputs of young, terrestrial organic matter across much of the MAB shelf and surface slope waters.

All MAB slope DOC samples were significantly lower in $\Delta^{14} \mathrm{C}$ than DOC from the same depths $(300-1000 \mathrm{~m})$ in the Sargasso Sea (Figure 6b), and as a group the slope values were lower than the average $\Delta^{14} \mathrm{C}$-DOC value for deep $(>1000 \mathrm{~m})$ Sargasso waters

Figure 6. (a) Concentrations, (b) $\Delta^{14} \mathrm{C}$ of DOC and (c) $\delta^{13} \mathrm{C}$ of $D O C$ as a function of salinity for all samples analyzed in the MAB, April 1994. Details of linear regressions are discussed in text. The four points lying above the conservative mixing line in Figure 6a are all from southern transect 8 shallow shelf and slope waters and are not included as part of the linear regression. For $\Delta^{14} \mathrm{C}$ versus salinity (Figure 6b), the regression includes only shelf and shallow slope (5 m depth) waters. Mean $\Delta^{14} \mathrm{C}$-DOC values for $3-100 \mathrm{~m}$ $(-238 \pm 17 \% ; n=5), 300-1000 \mathrm{~m}(-317 \pm 57 \% ; n=4)$ and $>1000 \mathrm{~m}(-394 \pm 13 \% ; n=9)$ in the Sargasso Sea (SS) are plotted for comparison. For $\delta^{13} \mathrm{C}$ versus salinity (Figure 6c), linear regressions with (solid line) and without (dashed line) southern transect 8 slope values are plotted separately, and yielded $r^{2}$ values of 0.396 and 0.629 , respectively. Also in Figure $6 \mathrm{c}$, mean $\delta^{13} \mathrm{C}-$ DOC values for $3-1000 \mathrm{~m}(-21.1 \pm 0.1 \%$; $n=10)$ and $>1000 \mathrm{~m}$ $(-20.8 \pm 0.3 \% ; n=10)$, and $>1000 \mathrm{~m}(-394 \pm 13 \% 0 ; n=9)$ in the SS are plotted for comparison. Sargasso Sea data from Bauer et al. [1992a, 1992b] and Druffel et al. [1992]. 

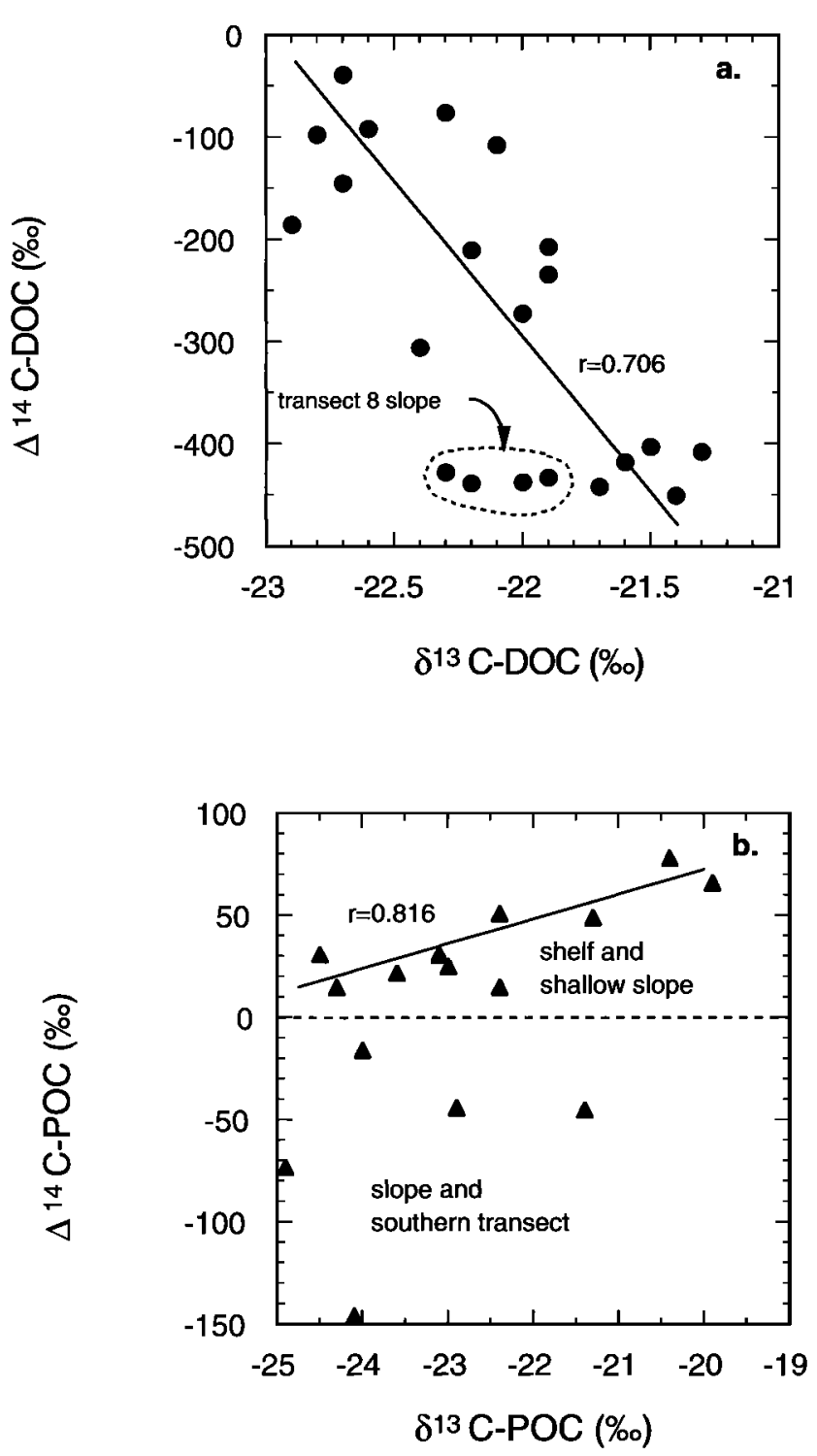

Figure 7. Relationships between $\Delta^{14} \mathrm{C}$ and $\delta^{13} \mathrm{C}$ of (a) DOC and (b) POC for all Mid-Atlantic Bight samples, April 1994. Details of correlations are discussed in text. The correlation in Figure $7 \mathrm{~b}$ does not include the samples from the deep slope and southern MAB.
(Figure 6b). This strongly suggests that there is a source(s) of ${ }^{14} \mathrm{C}$ depleted DOC to these deeper continental slope waters that is older than the DOC found in even the deepest, central-most part of the North Atlantic gyre [Bauer and Druffel, 1998].

The terrestrial versus marine character of both the ${ }^{14} \mathrm{C}$-enriched and depleted DOC in MAB waters may be partly elucidated by examining the relationships between $\delta^{13} \mathrm{C}-\mathrm{DOC}$ and salinity, as well as between $\delta^{13} \mathrm{C}$-DOC and $\Delta^{14} \mathrm{C}$-DOC. Only $\sim 40 \%$ of the total variance in $\delta^{13} \mathrm{C}-\mathrm{DOC}$ is explained by salinity when all samples are considered $\left(y=0.16 x-27.45 ; r^{2}=0.396 ; n=21\right.$; Figure $6 \mathrm{c}$ ). However, the samples from the southern MAB slope (which are also among the highest salinity samples) are clearly more depleted in ${ }^{13} \mathrm{C}$ than the other high salinity samples. The $\delta{ }^{13} \mathrm{C}$-DOC values versus salinity relationship is considerably stronger $\left(y=0.22 x-29.41 ; r^{2}=0.629 ; n=18\right)$ when these southern MAB slope values are excluded (Figure 6c). The anomalous nature of the southern MAB slope is further emphasized by the relationship between $\Delta^{14} \mathrm{C}-\mathrm{DOC}$ and $\delta^{13} \mathrm{C}$-DOC (Figure 7a), where in spite of the significant correlation $(y=-227 x-5300 ; r=$ $0.706, P<0.01, n=21$ ), the ${ }^{14} \mathrm{C}$ - and ${ }^{13} \mathrm{C}$-depleted values from southern $\mathrm{MAB}$ transect 8 slope waters are distinguishable from the other samples. The overall relationship in Figure $7 \mathrm{a}$ indicates that ${ }^{13} \mathrm{C}$-depleted material derived from terrestrial and freshwater sources contributes the majority of ${ }^{14} \mathrm{C}$-enriched DOC to MAB shelf and slope waters. However, the greater variability in $\delta^{13} \mathrm{C}$ DOC at very low $\Delta^{14} \mathrm{C}$ values, coupled with the apparent inputs of DOC in these waters (Figure 6a), indicates that there is an isotopically distinct source of ${ }^{13} \mathrm{C}$ - and ${ }^{14} \mathrm{C}$-depleted $\mathrm{DOC}$ to the outer reaches of the southern MAB.

We may calculate the $\Delta^{14} \mathrm{C}$ values of the DOC that must be added to the conservative DOC versus salinity relationship in the four shallow southern MAB samples in order to satisfy the observed versus predicted concentrations and $\Delta^{14} \mathrm{C}$ values (Table 2 and Figures $6 a$ and $b$ ). The predicted values for DOC concentration and $\Delta^{14} \mathrm{C}$ were derived by using the conservative relationship for each parameter as a function of salinity (shown in Figures $6 a$ and $b$ and described previously). A similar exercise for calculating $\delta^{13} \mathrm{C}$ of added DOC is not practical owing to the high degree of similarity of observed and predicted $\delta^{13} \mathrm{C}$ values (Table 3). The results of these calculations (Table 3) indicate that the $\Delta^{14} \mathrm{C}$ of the added DOC in the shallow southern MAB is not constant but rather ranges from modern $(70 \%)$ in inshore waters (station $62 ; 5 \mathrm{~m}$ depth) to extremely depleted $(-317 \%$ ) offshore (station 55; $5 \mathrm{~m}$ depth).

The physical and chemical factors affecting the distributions and characteristics of DOC and POC are likely unique for these two major pools of organic matter [Hedges et al., 1986; Hedges and Keil, 1999]. Indeed, there is no a priori reason that DOC and suspended POC in the MAB or other systems should resemble

Table 3. Observed and Predicted DOC Concentrations, $\Delta^{14} \mathrm{C}$, and $\delta^{13} \mathrm{C}$ in Shallow Southern MAB Samples ${ }^{\mathrm{a}}$

\begin{tabular}{|c|c|c|c|c|c|c|c|c|c|c|}
\hline \multirow[b]{2}{*}{ Station } & \multirow[b]{2}{*}{ Depth, m } & \multirow[b]{2}{*}{ Salinity, psu } & \multicolumn{3}{|c|}{ DOC, $\mu M$} & \multicolumn{3}{|c|}{$\Delta^{14} \mathrm{C}, \%$} & \multicolumn{2}{|c|}{$\delta^{13} \mathrm{C}, \% \mathrm{o}$} \\
\hline & & & Obs. & Pred. ${ }^{b}$ & Added $^{c}$ & Obs. & Pred. ${ }^{b}$ & Added $^{\mathrm{d}}$ & Obs. & Pred. $^{b}$ \\
\hline 62 & 5 & 32.73 & 112 & 79 & 33 & -98 & -168 & 70 & -22.8 & -22.2 \\
\hline 58 & 5 & 33.27 & 111 & 73 & 38 & -145 & -188 & -62 & -22.7 & -22.1 \\
\hline 58 & 40 & 35.72 & 69 & 44 & 25 & -272 & -278 & -261 & -22.0 & -21.6 \\
\hline 55 & 5 & 36.16 & 83 & 39 & 44 & -306 & -294 & -317 & -22.4 & -21.5 \\
\hline
\end{tabular}

${ }^{\mathrm{a}}$ Estimated amounts and $\Delta^{14} \mathrm{C}$ of the added fraction for these four samples are also given.

${ }^{b}$ Predicted values determined by the conservative linear relationships for DOC and $\Delta^{14} \mathrm{C}$ of DOC in Figures $6 a$ and $b$, respectively. See text for details.

${ }^{c}$ Added DOC concentrations are the difference between observed and predicted values.

${ }^{\mathrm{d}}$ Values for $\Delta{ }^{14} \mathrm{C}$ of added DOC were determined by isotopic mass balance, where $\left[(\mu M)\left(\Delta{ }^{14} \mathrm{C}\right)\right]_{\text {observed }}=\left[(\mu M)\left(\Delta{ }^{14} \mathrm{C}\right)_{\text {predicted }}\right]+\left[(\mu M)\left(\Delta{ }^{14} \mathrm{C}\right)\right]_{\text {added }}$ and $\Delta^{14} \mathrm{C}$ added is solved for. 
each other with respect to isotopic signatures (i.e., sources and residence times) or molecular composition. Although DOC and POC derived directly from unaltered source materials may resemble each other isotopically and even molecularly, a number of processes such as sorption, desorption, selective degradation (both biotic and abiotic), etc. may differentiate and segregate these two major pools in a number of respects in different aquatic systems [Kiel et al., 1997; Hedges and Keil, 1999]. Indeed, in those few studies where both $\Delta^{14} \mathrm{C}$ and $\delta^{13} \mathrm{C}$ of DOC and POC have been examined, large differences have been observed [Hedges et al., 1986; Trumbore et al., 1992; Druffel et al., 1992], indicating that DOC and POC can have different sources and/or vastly different residence times.

The magnitudes and ranges in $\Delta^{14} \mathrm{C}$ and $\delta^{13} \mathrm{C}$ values for suspended POC contrast sharply with those for DOC in the MAB (Table 2 and Figures 8 and 9). In general, $\Delta^{14} \mathrm{C}$ values of $P O C$ were much more enriched in bomb carbon and spanned a much narrower range than DOC, indicating that the majority of POC derived from more recent (i.e., younger) sources than DOC. Conversely, the range of $\delta^{13} \mathrm{C}$ values was much broader for POC than for DOC (Table 2 and Figures 8 and 9) and clearly indicated a stronger contribution to POC from terrestrial carbon in much of the $\mathrm{MAB}$. In addition, none of the numerous significant relationships that were noted for the various DOC parameters were observed for POC (plots not shown). However, as shown in Figure $7 \mathrm{~b}$, there appeared to be a significant relationship $(y=11.41 x+295 ; r=$ $0.816, P<0.01, n=9$ ) between $\Delta^{14} \mathrm{C}$ and $\delta^{13} \mathrm{C}$ of POC in shelf and shallow slope waters. This relationship did not hold for deep slope and southern transect samples where there was clearly a much older, ${ }^{14} \mathrm{C}$-depleted source of POC that spanned the entire range of $\delta^{13} \mathrm{C}$ (Figure $7 \mathrm{~b}$ ).

One or more factors may contribute the anomalous DOC and POC isotopic values observed in the southern MAB (both DOC and $\mathrm{POC}$ ) and MAB slope waters (POC). The first possibility is that these samples contain larger amounts of old, terrestrial organic matter (Figures $7 \mathrm{a}$ and $7 \mathrm{~b}$ ). One of the dominant inputs of terrestrial organic matter to this region is expected to be the watershed of the Chesapeake Bay and its numerous subestuaries. Aside from the southern slope samples, the other MAB $\Delta^{14} \mathrm{C}-\mathrm{DOC}$ values indicate that terrestrial inputs carry with them a significantly ${ }^{14} \mathrm{C}$-enriched component. In addition, the generally conservative behavior of both DOC and its isotopes in the other MAB waters (Figures 6a-6c) do not support a strong internal source(s) to them. The enrichment in bomb ${ }^{14} \mathrm{C}$ of total DOC from low salinity waters in the Chesapeake Bay region has also been observed by Raymond [1999] and Raymond and Bauer [2000], who reported mean $\Delta^{14} \mathrm{C}$ values of $220 \pm 21 \%$ (mean $\delta^{13} \mathrm{C}=-28.4 \pm 0.5 \% ; n=4$ ) in the freshwater end-member of the York River estuary, decreasing to an average of $50 \%$ at the confluence (15-16 psu salinity) of the York and Chesapeake Bay. In contrast, Guo et al. [1996] reported nearly constant $\Delta^{14} \mathrm{C}$ (mean of $-1 \pm 14 \%, n=6$ ), but relatively more variable $\delta^{13} \mathrm{C}$ (mean of $-27.8 \pm 2.2 \%$ ), values for the highmolecular weight $(>1000$ Daltons, comprising $52-65 \%$ of total Chesapeake Bay DOC) component of DOC throughout the Chesapeake Bay (5.0-25.0 psu salinity). In both of these studies, $\Delta^{14} \mathrm{C}$ values for ${ }^{13} \mathrm{C}$-depleted DOC from the Bay and a major subestuary (the York) are elevated, generally ruling them out as sources of old, ${ }^{14} \mathrm{C}$-depleted terrestrial DOC to the southern MAB.

A second possible source of the ${ }^{14} \mathrm{C}$ - and ${ }^{13} \mathrm{C}$-depleted $\mathrm{DOC}$ in the southern MAB is the input of an even more highly ${ }^{14} \mathrm{C}$ - and ${ }^{13} \mathrm{C}$-depleted component to the larger total DOC pool within these shelf waters. Guo et al. [1996] reported $\Delta^{14} \mathrm{C}$ values $(-403$ to $-376 \%$ ) for the 1000 Dalton fraction in southern MAB deep slope waters $(28-42 \%$ of DOC) that were slightly higher than the total DOC in the present study (Table 2). In contrast, these workers also observed extremely low $\Delta^{14} \mathrm{C}(-709$ to $-442 \%)$ and $\delta^{13} \mathrm{C}(-28.3$ to $-23.9 \%$ ) values in the very high molecular weight fraction
( $>10,000$ Daltons, $3-6 \%$ of total DOC in MAB waters) of DOC Guo et al. [1996] speculated that the anomalous values were a result of very old "benthic colloids" that remain in the water column following sediment resuspension [Guo and Santschi, 1999].

The $\Delta^{14} \mathrm{C}$ and $\delta^{13} \mathrm{C}$ values of total sedimentary organic carbon from this region indicate that both are generally enriched relative to total DOC, its >10,000 Dalton component [Guo et al., 1996], and total suspended $\mathrm{POC}$ in the southern $\mathrm{MAB}$ and $\mathrm{MAB}$ slope. The $\Delta^{14} \mathrm{C}$ values for surface sedimentary organic carbon from 501 to $1027 \mathrm{~m}$ depth along the northern North Carolina slope $\left(36^{\circ} 20^{\prime} \mathrm{N}\right.$ transect) ranged from about -160 to $-120 \%$ (C. J. Thomas, et al., The effects of irrigation on porewater chemistry, sedimentary fluxes and benthic carbon budgets for the North Carolina slope, submitted to Deep Sea Res., Part II, 2001, hereinafter referred to as Thomas et al., submitted manuscript, 2001), with corresponding $\delta^{13} \mathrm{C}$ values of -21.2 to $-18.7 \%$ [Blair et al., 1994]. In midslope $(1165 \mathrm{~m})$ surficial sediments of the central MAB, Anderson et al [1994] reported a $\Delta^{14} \mathrm{C}$ value of $-151 \%$, while Tanaka et al. [1991] observed mean $\Delta^{14} \mathrm{C}$ and $\delta^{13} \mathrm{C}$ values of $-251 \pm 145 \%$ and $-19.9 \pm 0.4 \%$, respectively, for northern MAB shelf $(78 \mathrm{~m})$ and slope $(2700 \mathrm{~m})$ surficial sediments. Thus, if sedimentary organic matter contributes to the ${ }^{14} \mathrm{C}$ - and ${ }^{13} \mathrm{C}$-depleted $\mathrm{DOC}$ in the southern $\mathrm{MAB}$ and to $\mathrm{POC}$ in slope waters, it must be a component that is isotopically distinct (i.e., generally more depleted in ${ }^{14} \mathrm{C}$ and ${ }^{13} \mathrm{C}$ ) from average sediment organic matter. While sediments may not constitute a direct source of organic matter to the DOC pool, selective fractionation of isotopically distinct sedimentary and pore water components [Guo and Santschi, 1999] during resuspension and hydrodynamic sorting [Keil et al., 1994a], desorption from particles [Wang and Lee, 1993; Kiel et al., 1997], or from pore water diffusion [Bauer et al., 1995] may help account for the generally lower $\Delta^{14} \mathrm{C}$ and $\delta^{13} \mathrm{C}$ values for DOC and POC observed in the southern MAB and in MAB slope waters.

One final possibility is the contribution of small amounts of petroleum hydrocarbons from seeps. Although specific hydrocarbon seeps have not been identified unequivocally in the MAB, elevated concentrations of methane in the MAB water column and formerly living seep and vent communities and organisms in the vicinity of the Baltimore and Wilmington Canyons have been found (M. Scranton, personal communication, 2000). This suggests that seeps could be a source of ${ }^{14} \mathrm{C}$ - and ${ }^{13} \mathrm{C}$-depleted fossil carbon to this region and possibly to present-day DOC and POC pools.

\subsection{DOC Inputs and Cycling in the Middle Atlantic Bight}

We may utilize the stable and radiocarbon isotopic compositions of DOC (and POC, see section 4.3) to estimate the marine versus terrestrial (including riverine) contributions to the total DOC pool in different parts of the MAB. Because ${ }^{14} \mathrm{C}$ has a far greater dynamic range than ${ }^{13} \mathrm{C}$ in naturally occurring organic matter, including that analyzed in this study, we can compare the estimates derived from these two isotopes to other available biomarker-based estimates of terrestrial contributions in margin environments. Typically, the relative contributions of different sources of organic matter to a given sample are estimated using single isotopes (e.g., $\delta^{13} \mathrm{C}, \delta^{15} \mathrm{~N}, \delta^{34} \mathrm{~S}$, or $\Delta^{14} \mathrm{C}$, etc.) and by knowing or assuming the isotopic "end-member" components contributing to the sample. A linear mixing model is then applied to establish the relative contributions of the different sources. In simple or well-constrained systems, single isotope linear mixing models are often adequate for first-order approximations of the sources contributing to a sample. However, the number and isotopic variability of autochthonous and allochthonous sources of organic matter in coastal environments is much greater than in many other aquatic environments. In such systems, the use of multiple natural isotopes may provide a greater degree of differ- 

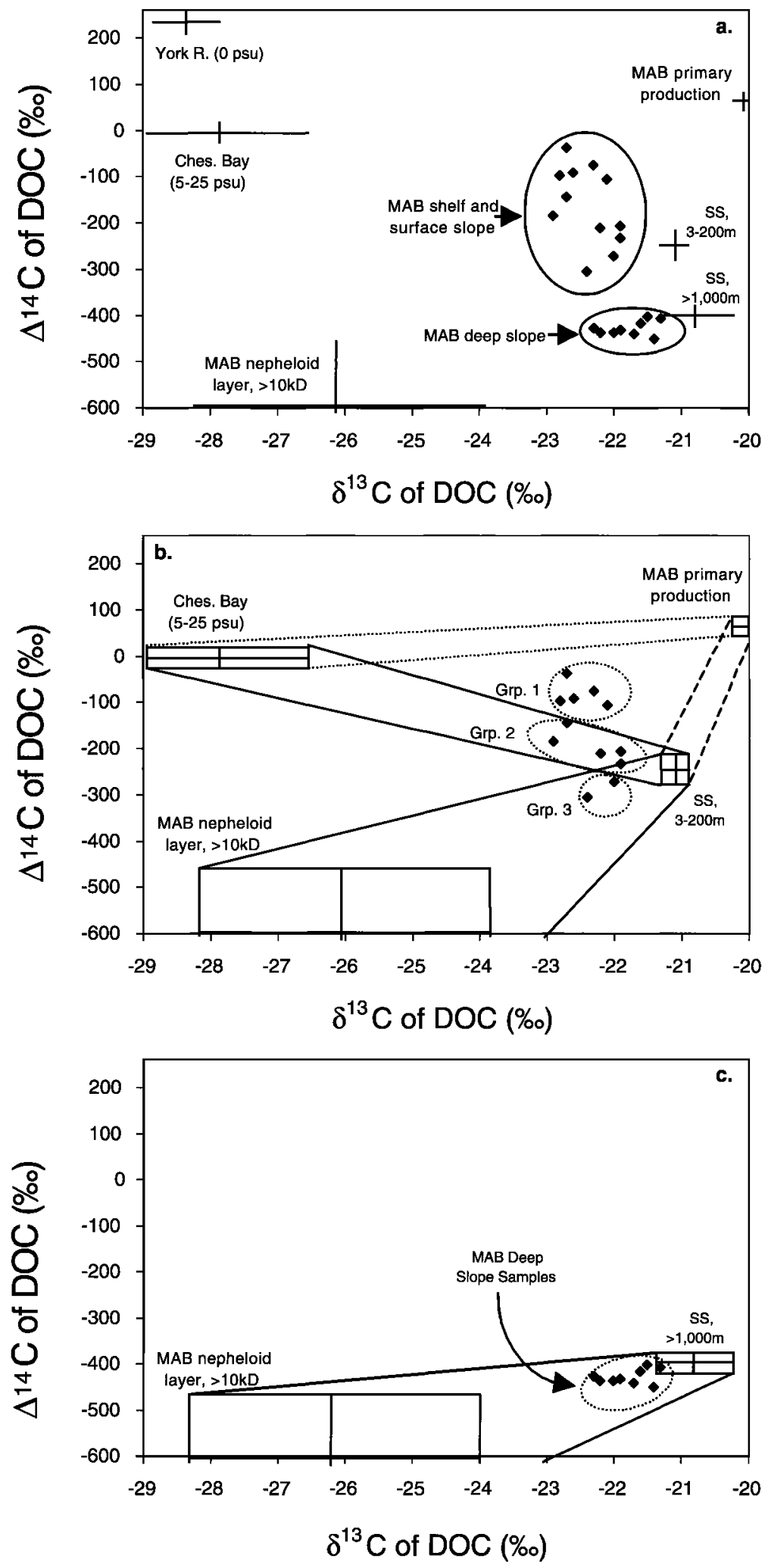

Figure 8. (a) Ranges in $\Delta^{14} \mathrm{C}$ and $\delta^{13} \mathrm{C}$ of potential sources of DOC to Mid-Atlantic Bight shelf and slope waters. Isotope values for potential sources were obtained from the following: York River total DOC [Raymond and Bauer, 2001a, 2001b]; Chesapeake Bay $>1 \mathrm{kD}$ material and MAB $>10 \mathrm{kD}$ nepheloid layer material [Guo et al., 1996]; Sargasso Sea (SS) total DOC [Bauer et al., 1992a, 1992b; Druffel et al., 1992]; MAB primary production, based on $\Delta^{14} \mathrm{C}$ and $\delta^{13} \mathrm{C}$ values for DIC in this study (see Table 2). (b) The $\Delta^{14} \mathrm{C}$ versus $\delta^{13} \mathrm{C}$ fields of potential source combinations of DOC to MAB shelf and surface slope waters and (c) MAB deep slope waters. See text and Table 5 for details. 

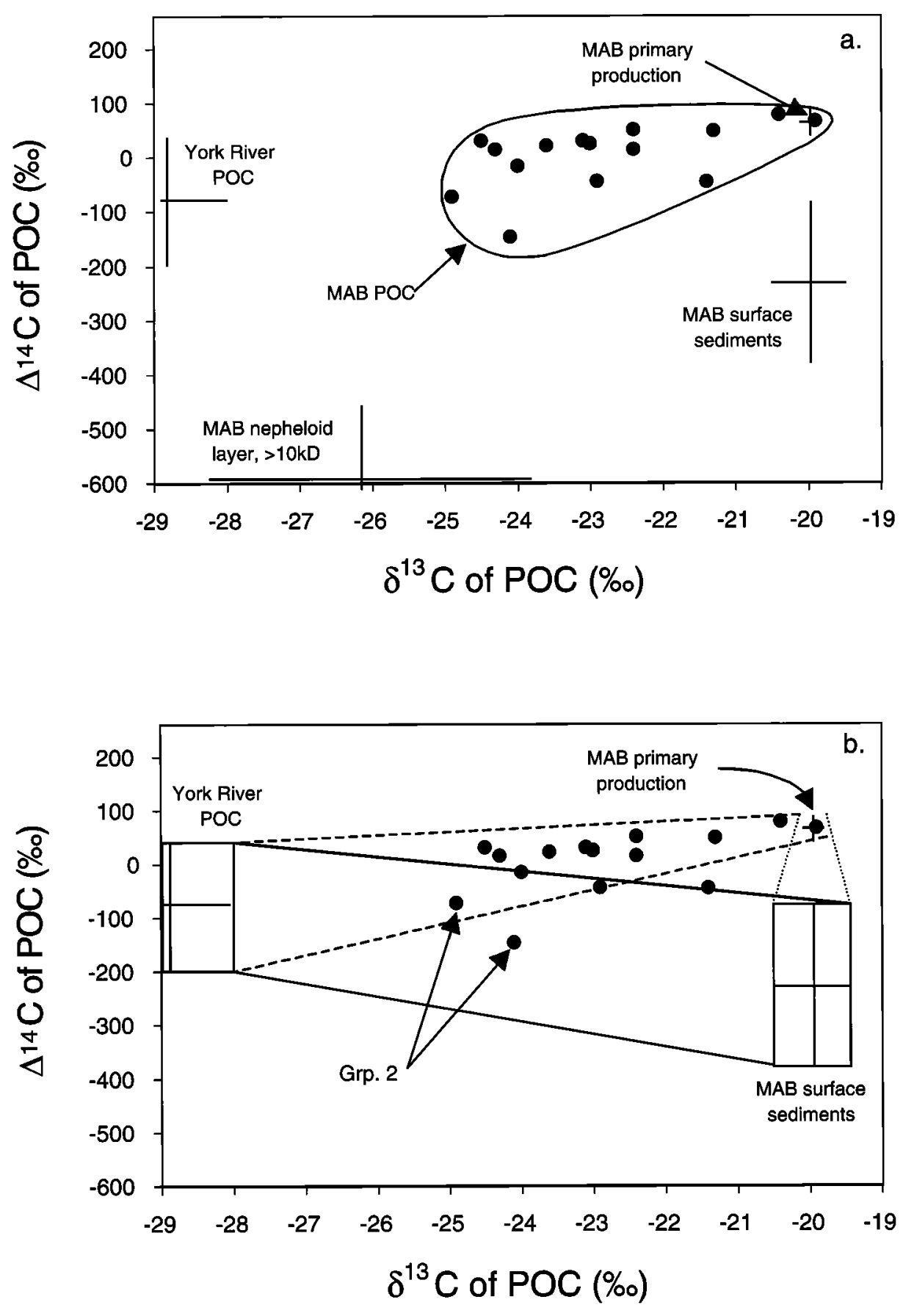

Figure 9. (a) Ranges in $\Delta^{14} \mathrm{C}$ and $\delta^{13} \mathrm{C}$ of potential sources of suspended $\mathrm{POC}$ to Mid-Atlantic Bight shelf and slope waters. Isotope values were obtained from the following sources: York River suspended POC [Raymond and Bauer, $2001 \mathrm{~b}$ ]; MAB $>10 \mathrm{kD}$ nepheloid layer material [Guo et al., 1996]; MAB surface sediments [Tanaka et al., 1991; Anderson et al., 1994]; MAB primary production, based on $\Delta^{14} \mathrm{C}$ and $\delta^{13} \mathrm{C}$ values for DIC in this study (see Table 2). (b) $\Delta^{14} \mathrm{C}$ and $\delta^{13} \mathrm{C}$ fields of potential source combinations of POC to MAB shelf and slope waters. See text and Table 5 for details.

entiation between multiple sources than single isotopes [Williams et al., 1992]. The same principles and mixing equations hold for the application of multiple isotopes of the same element (i.e., $\Delta^{14} \mathrm{C}$ and $\delta^{13} \mathrm{C}$ ) as for multiple stable isotopes of different elements [Fry and Sherr, 1984; Peterson and Howarth, 1987; Michener and Schell, 1994; Kwak and Zedler, 1997]. Furthermore, the use of $\Delta^{14} \mathrm{C}$ and $\delta^{13} \mathrm{C}$ simultaneously should provide a greater degree of specificity for organic carbon than multiple isotopes of different elements (e.g., $\delta^{13} \mathrm{C}$ and $\delta^{15} \mathrm{~N}$ ) used for studies of more general organic matter sources and cycling.

The potential sources of DOC to MAB shelf and slope waters for which $\Delta^{14} \mathrm{C}$ and $\delta^{13} \mathrm{C}$ information are available are shown in Table 4 (means) and plotted in Figure 8a (means and ranges). These sources include (1) total freshwater DOC from Chesapeake Bay, as represented by one of its major subestuaries, the York River estuary [Raymond and Bauer, 2001a, 2001b], (2) the high 
Table 4. Mean $\Delta^{14} \mathrm{C}$ and $\delta^{13} \mathrm{C}$ Values of Potential DOC and POC Sources Used to Calculate Relative Contributions to DOC and POC in the Mid-Atlantic Bight ${ }^{\mathrm{a}}$

\begin{tabular}{|c|c|c|c|}
\hline Potential Source & Mean $\Delta^{14} \mathrm{C}, \%$ & Mean $\delta^{13} \mathrm{C}, \%$ & Reference \\
\hline \multicolumn{4}{|c|}{ DOC Sources } \\
\hline York River; freshwater DOC & 200 & -28.4 & Raymond and Bauer [2001a] \\
\hline Chesapeake Bay (5-25 psu); HMW ( $>1 \mathrm{k} D$ ) DOC & -1 & -27.8 & Guo et al. [1996] \\
\hline Deep MAB VHMW $(>1 \mathrm{k} D)$; DOC & -580 & -26.4 & Guo et al. [1996] \\
\hline MAB primary production ${ }^{b}$ & 55 & $-20^{\mathrm{c}}$ & this study \\
\hline Deep Sargasso; DOC & -394 & -20.8 & Bauer et al. $[1992 \mathrm{a}, 1992 \mathrm{~b}]$ \\
\hline Surface Sargasso; DOC & -238 & -21.2 & Druffel et al. [1992] \\
\hline \multicolumn{4}{|c|}{ POC Sources } \\
\hline York River; freshwater POC & -68 & -29.1 & Raymond and Bauer [2001b] \\
\hline Deep MAB VHMW $(>10 \mathrm{k} D)$; DOC & -580 & -26.4 & Guo et al. [1996] \\
\hline MAB primary production ${ }^{b}$ & 55 & $-20^{c}$ & this study \\
\hline MAB surface sediments & -251 & -20.1 & Tanaka et al. [1991] \\
\hline & -151 & nd & Anderson et al. [1994] \\
\hline
\end{tabular}

\footnotetext{
${ }^{\text {a }}$ See Figures 8 and 9, and Table 5. nd, not determined.

${ }^{\mathrm{b}} \mathrm{On}$ the basis of $\Delta^{14} \mathrm{C}$ and $\delta^{13} \mathrm{C}$ of DIC (Table 2).

${ }^{c}$ Assumes fractionation of $-19 \%$ during $\mathrm{CO}_{2}$ fixation by marine phytoplankton.
}

molecular weight $(>1 \mathrm{k} D)$ component of DOC from the mainstem of Chesapeake Bay [Guo et al., 1996], (3) the very high molecular weight $(>10 \mathrm{k} D)$ component of MAB near-bottom nepheloid material [Guo et al., 1996], (4) present-day primary production in MAB surface waters, estimated from the $\Delta^{14} \mathrm{C}$ and $\delta^{13} \mathrm{C}$ values of DIC (Table 2), and (5) previous estimates of fully marine values for the surface and deep Sargasso Sea [Bauer et al., 1992a, 1992b; Druffel et al., 1992], taken to be representative of open North Atlantic waters in general. Use of the isotopic values of Chesapeake Bay $>1 \mathrm{k} D$ and deep MAB $>10 \mathrm{k} D$ fractions of DOC [Guo et al., 1996] as terrestrial/riverine end-members is supported by the findings of Mitra et al. [2000] who showed that both of these components contained elevated amounts of lignin-derived phenols originating from terrestrial plants.

The $\Delta^{14} \mathrm{C}$ versus $\delta^{13} \mathrm{C}$ distributions of DOC samples measured in this study (Figure 8a) are consistent with DOC in the MAB being comprised of one or more of the indicated potential sources. In addition, $\Delta^{14} \mathrm{C}$ versus ${ }^{13} \mathrm{C}$ distributions for DOC from MAB shelf and shallow slope waters lie between different potential endmembers (i.e., surface Sargasso, Chesapeake Bay/York River, and MAB primary production) than DOC from deeper slope waters (i.e., deep Sargasso and MAB nepheloid layer material). We hypothesize that this is a result of unique sources and ages of DOC to these two major water types. It is also possible from Figure $8 \mathrm{a}$ for admixtures of MAB modern primary production and $>10 \mathrm{k} D$ nepheloid material to give $\Delta^{14} \mathrm{C}$ and $\delta^{13} \mathrm{C}$ values similar to those observed in MAB shelf and shallow slope waters. However, two factors argue against this proposed scenario. First, the $>10 \mathrm{k} D^{14} \mathrm{C}$ depleted material in deeper waters comprises only $3-6 \%$ of the total DOC [Guo et al., 1996] and second, the observations of Guo et al. [1996] indicate that in shallow waters of the MAB, the $>10$ $\mathrm{k} D$ fraction was actually similar in both $\Delta^{14} \mathrm{C}$ and $\delta^{13} \mathrm{C}$ to values for MAB primary production (Figure 8a). Furthermore, as demonstrated by Druffel et al. [1992], Sargasso Sea surface ocean DOC can be adequately described as a combination of old, deep material and young material from primary production.

For purposes of the following exercise, we assume that the major inputs to the different shelf and surface slope waters (shown as groups 1, 2 and 3 in Figure 8b) can be described reasonably by a combination of (1) surface Sargasso material (which itself is comprised of deep Sargasso material and recent primary production [Bauer et al., 1992a, 1992b; Druffel et al., 1992]), (2) Chesapeake Bay material (which must also contain some York River material), and (3) material derived from contemporary MAB primary production. The mixing fields (Figure $8 \mathrm{~b}$ ) indicate that all but two of the samples (group 3 ) can be described by mixtures of these three major sources. Group 3 samples (i.e., from the southern MAB) must have an additional source of older material which is best represented by the ${ }^{14} \mathrm{C}$ - and ${ }^{13} \mathrm{C}$-depleted nepheloid material (see below). One interesting feature of this analysis is that within the framework of the available $\Delta^{14} \mathrm{C}$ and $\delta^{13} \mathrm{C}$ information, DOC in shelf and shallow slope waters cannot be described by a mixture of material derived exclusively from Chesapeake Bay/York River and MAB primary production: a significant contribution to all shelf and shallow slope waters is required from old, offshore oceanic DOC (Figure 8b).

In order to establish first-order estimates of the relative contributions of the major presumed sources of DOC to shelf and shallow slope waters, we used three-source isotopic mixing models similar to those of Fry and Sherr [1984] and Kwak and Zedler [1997]. The generalized mixing equation is

$$
X_{\mathrm{DOC}-\mathrm{MAB}}=f_{\mathrm{l}} X_{\mathrm{DOC}-\mathrm{fl}}+f_{2} X_{\mathrm{DOC}-\mathrm{f} 2}+\left(1-f_{1}-f_{2}\right) X_{\mathrm{DOC}-\mathrm{f} 3},
$$

where $X$ is the isotopic composition $\left(\Delta^{14} \mathrm{C}\right.$ or $\left.\delta^{13} \mathrm{C}\right)$ of DOC from the MAB samples for each of the identified potential sources. The value $f$ is the relative contribution of each of the three potential sources to the total DOC in the MAB samples, and $f_{1}+f_{2}+f_{3}=1.0$. Since there are two unknowns $\left(f_{1}\right.$ and $\left.f_{2}\right)$ in (1), the equation must be solved simultaneously using $\Delta^{14} \mathrm{C}$ and $\delta^{13} \mathrm{C}$. The contribution of the third potential source, $f_{3}$, is equal to $\left(1-f_{1}-f_{2}\right)$.

The results of these calculations (Table 5) indicate that shelf and shallow slope waters are dominated by DOC that is similar isotopically to that found in the open North Atlantic (Sargasso Sea). However, the DOC from different regions within the MAB contains varying and often significant amounts of material from in situ production and material that must arise from terrestrial/ riverine/estuarine (TRE) inputs. For group 1 (Figure $8 \mathrm{~b}$ and Table 5), which is dominated by shelf and shallow slope samples in the buoyant plume of the central and southern transects (Tables 1 and 2), up to a third of the DOC is TRE material, and slightly more $(25-43 \%)$ is recently derived MAB primary production. Group 2 samples (Figure $8 \mathrm{~b}$ ), which are dominated by the slightly higher salinity shelf and shallow slope waters of the northern transect (Tables 1 and 2), are comprised of lower amounts of DOC derived from both TRE $(9-25 \%)$ as well as MAB primary production $(0-12 \%)$ (Table 5$)$. Finally, the two anomalous southern transect samples (group 3) that lie outside of the mixing fields that contribute to the majority of shelf and shallow slope samples (Figure $8 \mathrm{~b}$ ) must have a component that is much older in order to account for the observed values. The 
Table 5. Estimates of Relative Inputs of Different Potential Sources of DOC and POC to the Mid-Atlantic Bight, Based on Results of Three-Source Isotopic Mixing Models ${ }^{\mathrm{a}}$

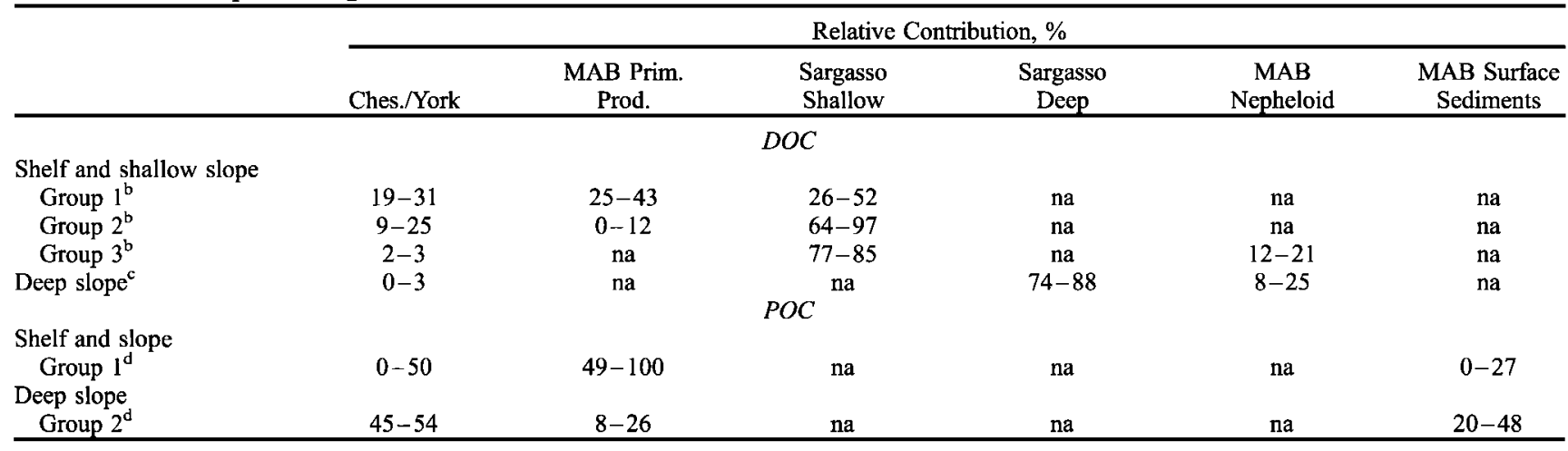

${ }^{a}$ See text for details. na, not applicable (end-member not used in mass balance).

${ }^{\mathrm{b}}$ As shown in Figure 8b.

${ }^{\mathrm{c}}$ As shown in Figure 8c.

${ }^{\mathrm{d}}$ As shown in Figure $9 \mathrm{~b}$.

only material that has been identified that can fulfill the requirement of a simultaneously ${ }^{14} \mathrm{C}$ - and ${ }^{13} \mathrm{C}$-depleted $\mathrm{DOC}$ component is the very high molecular weight DOC $(>10 \mathrm{k} D)$ from the nepheloid layer [Guo et al., 1996]. When this source is mass balanced against shallow Sargasso and TRE material, we find that it comprises $12-21 \%$ of the total DOC (Table 5), while younger TRE material represents only trace $(2-3 \%)$ inputs.

Following our approach for shelf and shallow slope waters, we assume that $\mathrm{MAB}$ deep slope DOC is composed predominantly of a combination of deep Sargasso, $>10 \mathrm{k} D$ nepheloid, and TRE materials (Figure 8c). Similar to the group 3 DOC samples (Figure $8 \mathrm{~b}$ ), we find that up to $25 \%$ of the deep slope DOC may be comprised of a presumably highly aged, ${ }^{13} \mathrm{C}$-depleted high molecular weight component (Table 5). On the basis of several other recent studies [Druffel and Williams, 1990; Sherrell et al., 1998; Bianchi et al., 1998; Bauer and Druffel, 1998; Druffel et al., 1998; Honda et al., 2000], lateral inputs of organic matter from both the nepheloid layer and sediments in continental margins are plausible sources of organic matter not only to slope waters but to even more oceanic waters. The much steeper vertical gradient in $\Delta^{14} \mathrm{C}$ POC in MAB slope waters compared to the open North Atlantic [Druffel et al., 1992] strongly suggests that margins are a source of ${ }^{14} \mathrm{C}$-depleted POC (and by similar reasoning, DOC) to the water column. The fact that the high molecular weight component has substantial terrestrial $\delta^{13} \mathrm{C}$ character and is concomitantly so old [Guo et al., 1996; Guo and Santschi, 1999], suggests that slope sediments could represent a temporary "aging reservoir" for terrestrial and shelf/slope-derived organic matter. This material, possibly deposited initially in slope and certain shelf sediments (e.g., as in the southern MAB) as POC or mineral-sorbed DOC [Mayer, 1994; Kiel et al., 1997], may then undergo partial postdepositional desorption, hydrolysis, and degradation in sediments prior to being re-released to the water column pool of DOC [Burdige and Gardner, 1998; Burdige et al., 1999; Alperin et al., 1999]. If it occurs, this proposed mechanism is significant in that it would result in margin sediments providing a source of "preaged" terrestrial and shelf/slope primary production to the deep ocean directly [Bauer et al., 1995]. Finally, on the basis of both past and recent evidence [Spiker and Rubin, 1975; Raymond and Bauer, 2000], we cannot, without further information, rule out the possibility that rivers themselves transport directly a significant amount of aged terrestrial DOC to certain coastal systems. For example, Spiker and Rubin [1975] reported $\Delta^{14} \mathrm{C}$ values for total DOC in the Rappahannock and Susquehanna Rivers of -91 and $-81 \%$, respectively, while Raymond and Bauer [2001b] have found mean $\Delta^{14} \mathrm{C}$-DOC values of $-158 \%$ in the freshwater Hudson River.

\subsection{POC Inputs and Cycling in the Middle Atlantic Bight}

On the basis of the $\Delta^{14} \mathrm{C}$ and $\delta^{13} \mathrm{C}$ signatures of suspended POC (Figures $4 a-4 i$ and Figure $7 b$ ), we may infer that the POC has unique source and age functions from the total $D O C$ in the MAB (Figures 2a-2i and Figure 7a). The physical, chemical, and biological processes responsible for transporting DOC and POC to shelf and slope waters and sediments, and subsequently transforming it once it is there, are likely to be distinct. Hedges et al. [1986] and Raymond and Bauer [2001b] both observed riverine POC to be considerably lower in $\Delta^{14} \mathrm{C}$ than either total riverine DOC or humic substances, suggesting that particle-associated organic matter has a much longer residence time than DOC in the watersheds and basins of rivers, estuaries, and bays.

Another possible source to MAB shelf and slope waters of ${ }^{14} \mathrm{C}$ depleted POC with considerable terrestrial $\delta^{13} \mathrm{C}$ character is shelf and slope sediment resuspension from tidal and wind-driven mixing [Meade et al., 1975; Fischer, 1980; Csanady et al., 1988; Nittrouer and Wright, 1994] or even commercial trawling [Churchill, 1989]. However, the isotopic compositions of bulk sedimentary organic matter [Tanaka et al., 1991; Anderson et al., 1994; D. J. DeMaster et al., Deposition of bomb ${ }^{14} \mathrm{C}$ in continental slope sediments of the Mid-Atlantic Bight: Assessing organic matter sources and burial rates, submitted to Deep Sea Research, Part II, 2001) and of the presumed old, terrestrial very high molecular weight fraction derived from sediments in the MAB [Guo et al., 1996; Guo and Santschi, 1999], are not similar to our observed $\Delta^{14} \mathrm{C}$ and $\delta^{13} \mathrm{C}$ values of suspended POC (Figure 9a). Indeed, the majority of suspended POC in our MAB shelf and slope samples is best described by a combination of recent shelfslope primary production and material similar to that found in the freshwaters of the York River estuary [Raymond and Bauer, 2001b]. Because no $\Delta^{14} \mathrm{C}$ data on POC for the Chesapeake Bay proper are available, we must assume that the observed $\Delta^{14} \mathrm{C}$ - and $\delta^{13} \mathrm{C}$-depleted values for the York are representative of suspended POC from other parts of the Bay and of major rivers and estuaries of the Mid-Atlantic Coastal plain (and which has also been shown for several other temperate U.S. east coast rivers [Raymond and Bauer, 2001b]. While MAB surface sediments may also supply a fraction of organic matter to MAB suspended POC (e.g., to the two lowest $\Delta^{14} \mathrm{C}$ and $\delta^{13} \mathrm{C}$ slope samples), this contribution appears to be limited relative to MAB primary production and 
terrestrial/riverine sources (Figure $9 b$ ). Furthermore, the contribution of $>10 \mathrm{k} D$ HMW nepheloid material (Figure 9a) to the suspended POC would presumably be low or insignificant because this material would not normally be collected in the particulate $(>0.6 \mu \mathrm{m})$ fraction.

We note that while suspended POC is not well represented by the isotopic signatures of bulk sediments in the MAB, we cannot preclude the presence of a specific component of sediments that resembles a fraction such as the York POC. Anderson et al. [1994] observed the $\Delta^{14} \mathrm{C}$ of POC collected in particle traps in 1988 on the deep $(1000 \mathrm{~m}) \mathrm{MAB}$ slope to have a mean weighted value of $-85 \%$ $\left(\delta^{13} \mathrm{C}\right.$ of this material was not measured), nearly identical to our value for the York $(-68 \%)$, and much lower than that measured in their shallow traps $(130 \mathrm{~m})$ where bomb- ${ }^{14} \mathrm{C}$ was present (mean weighted $\Delta^{14} \mathrm{C}=+35 \%$ ). The mean values for their deep traps were also significantly higher than the mean $\Delta^{14} \mathrm{C}$ of surface sediment organic carbon $(-151 \%)$ from the upper slope of the MAB [Anderson et al., 1994]. This indicates a likely contribution from younger, ${ }^{14} \mathrm{C}$-enriched material in their trap-collected $\mathrm{POC}$, which was deduced by these authors to have a strong, lateral component and would likely include suspended, as opposed to exclusively sinking, POC. Furthermore, a single $\Delta^{14} \mathrm{C}$ value reported for lignin phenols extracted from MAB surface slope sediments $(2700 \mathrm{~m}$ depth) was similar $(-327 \%$ ) to the value for bulk sedimentary organic carbon (-294\%o) [Tanaka et al., 1991], indicating that relic terrestrial material is indeed present in these sediments and, by inference, in some component of suspended POC.

Similar to our evaluation of the potential sources of organic matter to the $\mathrm{DOC}$ pool in the MAB, we may calculate the relative contributions of MAB primary production, TRE-POC (as represented by the York River values; Table 4), and surface sediments to the suspended POC of the MAB (Figure 9b; Table 5). We again solve (1) simultaneously using both $\Delta^{14} \mathrm{C}$ and $\delta^{13} \mathrm{C}$ values and assume inputs only from MAB primary production, York River POC, and MAB surface sediments. Results of these calculations show that the majority of POC samples (group 1) are dominated by simple two-component admixtures of organic matter represented by TRE material and MAB primary production (Table 5). Although generally of secondary importance to $\mathrm{MAB}$ primary production, ${ }^{14} \mathrm{C}$ - and ${ }^{13} \mathrm{C}$-depleted TRE material can comprise up to $50 \%$ of POC in the MAB. The relative importance of TRE material to the shelf-slope POC pool (and likely to the DOC pool as well) may be dependent on a number of factors such as seasonal and large, episodic discharges from the watershed, rivers, and estuaries [Ruzecki, 1981; Schubel and Pritchard, 1986]. It is noteworthy that only two of the observed POC values (group 2, station 46; 300 and $1000 \mathrm{~m}$ ) contain any significant amount of material $(20-48 \%)$ derived directly from sediments (Figure $9 \mathrm{~b}$ and Table 5) using this dual isotope approach. The remainder of the POC samples in the MAB can only be described adequately through admixtures of ${ }^{14} \mathrm{C}$ depleted terrestrial/riverine POC and ${ }^{14} \mathrm{C}$-enriched shelf and slope primary production. However, we must point out that this assessment may be biased because of the absence of $\delta^{13} \mathrm{C}$ data from the majority of northern and southern MAB deep slope samples (Table 2), which did not allow us to employ the dual isotope approach for evaluating the sources of organic matter to these samples. However, it is intriguing to note that the $750 \mathrm{~m}$ POC sample from the northern transect had a relatively depleted $\delta^{13} \mathrm{C}$ value $(-23.7 \%)$, similar to those of the central transect.

\subsection{Preliminary Organic ${ }^{14} \mathrm{C}$ Budget for Mid-Atlantic Bight Waters}

Previous estimates of organic carbon inputs, transformation, and cycling in ocean margin systems have been limited primarily to POC [Falkowski et al., 1988; Walsh et al., 1988; Walsh, 1991; Small, 1992; Biscaye et al., 1994], sediment organic matter burial
[Tanaka et al., 1991; Anderson et al., 1994; Goni et al., 1998; Thomas et al., submitted manuscript, 2001], or subfractions of DOC [Guo et al., 1996; Guo and Santschi, 1999]. The information from the present study on sources, ages, inputs, and standing stocks of both total DOC and POC allows for a more comprehensive assessment of the roles of these dominant pools to the organic carbon cycle in the northwest Atlantic Ocean margin. We herein focus our analysis on DOC because of its quantitative dominance over POC in all cases in the MAB but recognize that suspended POC has unique isotopic properties from the DOC that it may influence not only the POC of adjacent waters but also DOC through particle-solute interactions [Hedges and Keil, 1999]. We first consider shelf and shallow slope waters in our transport and flux estimates. This is followed by a separate estimate of the potential significance of inputs from the deep slope of the MAB.

The general circulation and water mass features of MAB shelf and upper slope waters suggest that it is a "leaky" system in which the majority (greater than $\sim 90 \%$ ) of total shelf water entering from the vicinity of George's Bank and Nantucket Shoals $(\sim 0.38 \mathrm{~Sv}$, where $\mathrm{Sv}=10^{6} \mathrm{~m}^{3} \mathrm{~s}^{-1}$ ) exchanges with slope and more seaward waters during its southwestward flow [Mountain, 1991; Loder et al., 1998]. A relatively small amount (less than $\sim 10 \%$ ) of the total transport is advected eastward in a coherent flow around Cape Hatteras [Mountain, 1991; Pietrafesa et al., 1994; Loder, 1998]. The isotopic characteristics of DOC and suspended POC of the ultimate subpolar source waters to the MAB (i.e., from the Labrador shelf and Greenland Current [Chapman and Beardsley, 1989]) are unknown, but the generally lower concentrations (Figures $2 \mathrm{a}-2 \mathrm{c}$ ) and ${ }^{14} \mathrm{C}$-depleted nature of DOC (Figures $2 \mathrm{~d}-$ 2f) throughout the northern transect suggest that an older, more refractory component enters the MAB from the northeast, and probably from the slope, at least periodically. The younger, more ${ }^{14} \mathrm{C}$-enriched DOC added to MAB shelf waters is therefore deduced to result from a combination of new shelf primary production and terrestrial/riverine/estuarine discharge.

MAB shelf waters (generally defined as less than $\sim 34.8 \mathrm{psu}$ ) are also higher in both DOC concentration and $\Delta^{14} \mathrm{C}$ than deeper slope and open North Atlantic waters (Figures $6 \mathrm{a}$ and $6 \mathrm{~b}$ ), and so we may estimate the amount of DOC and $\Delta^{14} \mathrm{C}$ "in excess" of these lower DOC and $\Delta^{14} \mathrm{C}$ values that are likely representative of source waters. Continuous, integrated salinity-dependent distributions of DOC concentrations and $\Delta^{14} \mathrm{C}$-DOC values in shelf waters are not practicable at this time, and we must rely on our upper $(\sim 115 \mu M$ and $-40 \%$ ) and lower $(\sim 70 \mu M$ and $-250 \%)$ values for each, across the range of salinities encountered in this study, in order to constrain these estimates. The most representative background DOC for these calculations is likely to be material that is similar in concentration and $\Delta^{14} \mathrm{C}$ to deeper slope DOC (means of $\sim 50 \mu M$ and $-430 \%$, respectively). We make this assumption owing to the proximity of slope waters to shelf waters (unlike the more remote deep Sargasso values) and which may be an episodic source of upwelled water to the shelf [Joyce et al., 1992; Gawarkiewicz et al., 1996]. The resulting range in surplus DOC concentrations in shelf and upper slope waters is therefore $20-65 \mu \mathrm{M}$. Constructing a simple isotopic mass balance, we estimate that the $\Delta^{14} \mathrm{C}$ values of the surplus DOC in MAB shelf and upper slope waters (<34.8 psu) are 200 and $260 \%$ for the low and high estimates of the DOC and $\Delta^{14} \mathrm{C}$ ranges, respectively. Both of these estimates are very close to the bomb-enriched mean $\Delta^{14} \mathrm{C}$ value for total bulk DOC of $210 \pm$ $40 \%(n=4)$ in freshwaters of the York River, a major tributary of Chesapeake Bay [Raymond, 1999; Raymond and Bauer, 2001a]. Present-day shelf primary production would also produce bombenriched DOC but at much lower levels $\left(\Delta^{14} \mathrm{C} \approx 50 \%\right.$ ) than riverine DOC. Clearly, there is a source(s) of ${ }^{14} \mathrm{C}$-enriched DOC to the MAB shelf resulting in this surplus of young DOC, a substantial part of which $(\sim 25-30 \%)$ has terrestrial $\delta^{13} \mathrm{C}$ character (Table 5). 
An inventory estimate of surplus DOC in MAB shelf and upper slope waters at the time of this study can be made by taking the differences (upper and lower) in concentrations between salinities $<34.8$ psu (Figure 6a) and deeper slope waters. Extrapolating the surplus DOC $(20-65 \mu \mathrm{M})$ to the total mean estimated volume $\left(3600 \mathrm{~km}^{3}\right)$ and mean replacement time (100 days) of MAB shelf water [Mountain, 1991], we estimate a total annual export of young, excess shelf/upper slope DOC of $\sim 3-9 \times 10^{12} \mathrm{~g} \mathrm{C} \mathrm{yr}^{-1}$ from the MAB. This is considered a maximum estimate of the export of the surplus DOC because it does not account for the loss of this material by bacterial degradation during the residence times of shelf and upper slope waters, which may be significant [Raymond and Bauer, 2000]. This young material is likely exported in buoyant, lower salinity waters [Hickey, 2000], and exchange may be enhanced to a significant degree by discrete advective features such as Ford filaments [Ford et al., 1952; Bates and Hansell, 1999], Gulf Stream rings [Joyce et al., 1992; Gawarkiewicz et al., 1996], and frontal eddies [Houghton et al., 1986; Churchill et al., 1993]. If the DOC in the MAB shelf $(\sim 950 \mathrm{~km}$ in length) is similar to other margin areas globally (estimated at $\sim 3.1 \times 10^{5} \mathrm{~km}$ mean length [Walsh, 1991]), then the global integrated export of margin DOC $\left(\sim 1-3 \times 10^{15} \mathrm{~g} \mathrm{C} \mathrm{yr}^{-1}\right)$ may be a significant term relative to both shelf net primary production $\left(\sim 5-6 \times 10^{15} \mathrm{~g} \mathrm{C} \mathrm{yr}^{-1}[\right.$ Walsh, 1988; Wollast, 1998]) and DOC discharged annually by rivers $\left(\sim 0.25 \times 10^{15} \mathrm{~g} \mathrm{C} \mathrm{yr}^{-1}\right.$ [Hedges et al., 1997]). When we perform the same exercise for suspended POC using upper $\left(190 \mu \mathrm{g} \mathrm{C} \mathrm{L}^{-1}\right)$ and lower $\left(\sim 3 \mu \mathrm{g} \mathrm{C} \mathrm{L}^{-1}\right)$ total POC concentrations (i.e., not using "surplus" values as for DOC and excluding the anomalously high value at station $58,40 \mathrm{~m}$ ) we calculate first-order estimates of $0.5-$ $2 \times 10^{12} \mathrm{~g} \mathrm{C} \mathrm{yr}^{-1}$ exported from the MAB, or $0.2-0.8 \times 10^{15} \mathrm{~g} \mathrm{C}$ $\mathrm{yr}^{-1}$ exported from margins globally, again assuming the MAB is representative. Similar to the DOC, a significant fraction of this exported POC (as much as half, Table 5) may be comprised of terrestrial, riverine (estimated at $\sim 0.15 \times 10^{15} \mathrm{~g} \mathrm{C} \mathrm{yr}^{-1} \mathrm{POC}$ discharged [Hedges et al., 1997]) and/or estuarine material of modern or relic age (Figures 9a and 9b). Clearly, more study is required of a greater number and variety of ocean margin systems to better constrain the export term within the framework of total margin carbon fluxes.

The fate of the young, surplus shelf DOC is uncertain. The evidence to date suggests that processes such as microbial and photochemical degradation [Mopper et al., 1991], selective sorption and replacement on mineral surfaces in margins [Kiel et al., 1997], and mixing with older, more refractory open ocean DOC [Druffel et al., 1992] may all play a role in rendering this young, surplus material (as well specific organic biomarkers of coastal and terrestrial organic matter [Moran et al., 1991; Opsahl and Benner, 1997]) difficult to differentiate against the much larger pool of old, oceanic DOC once it has been exported. These preliminary estimates of export are also subject to revision pending greater spatial and temporal coverage of different ocean margin systems.

A similar treatment of potential deep slope water contributions to margin export of DOC is more difficult because of our insufficient understanding of the magnitude of slope water exchanges and transports with the interior ocean. However, a cursory examination of the data from the MAB (Figures $2 \mathrm{c}$ and $2 \mathrm{f}$ and Figure $6 \mathrm{~b}$ ) shows that in all cases, deep slope waters have higher concentrations and lower $\Delta^{14} \mathrm{C}$ values of DOC than more oceanic waters represented by the Sargasso Sea. A simple isotopic mass balance of the DOC in deep slope waters $(\sim 50$ $\mu M$ and $-430 \%)$ versus the deep Sargasso ( 42 $\mu M$ and $-400 \%$ ) yields $\Delta^{14} \mathrm{C}$ of the surplus fraction $(\sim 8 \mu M)$ of about $-590 \%$; much older than the DOC of either the deep slope or Sargasso. Whether the input of this old DOC in slope waters is from slope sediments, seeps, upwelled deep waters, or other sources cannot be established without additional study. However, if representative of other slope waters globally, it may constitute a source of "pre-aged" DOC that at least in part accounts for the old observed ages of DOC in the open world ocean. The presumed transport of this deep slope material along isopycnal surfaces may provide a mechanism for its relatively rapid exchange with the open ocean [Jenkins, 1977; Bauer and Druffel, 1998; Sherrell et al., 1998; Hung et al., 1999]. A similar argument may be made for the suspended POC, which is more concentrated and has lower $\Delta^{14} \mathrm{C}$ values in MAB slope waters, than in the open North Atlantic [Bauer and Druffel, 1998].

Finally, a growing body of evidence indicates that organic material that can only be derived from ocean margins (including from the continents themselves) is transported great distances into the interior ocean. From a global ocean perspective, the existence of significant amounts ( $4-10 \%$ minimum) of unambiguous terrestrial biomarkers such as lignin in deep open ocean humic substances [Meyers-Schulte and Hedges, 1986] and high molecular weight [Opsahl and Benner, 1997; Opsahl et al., 1999] DOC is clear evidence that over oceanic mixing timescales, lateral inputs from margins must be important. Margins may thus occupy significant terms in the cycling and export of both young (from shelves) and old (from slopes) organic matter of both coastal marine and terrestrial origin.

Acknowledgments. We thank the crew of the R/V Columbus Iselin for assistance in sampling, and Dan Repeta for assistance and support as chief scientist. Michaele Kashgarian and John Southon of the Center for Accelerator Mass Spectrometry, Lawrence Livermore National Laboratory were extremely generous in making available resources and facilities for AMS ${ }^{14} \mathrm{C}$ analyses, and Eben Franks performed $\delta^{13} \mathrm{C}$ analyses. We thank Catherine Goyet for dissolved inorganic carbon measurements, and three anonymous reviewers for comments that improved the final manuscript. Curtis Olsen and George Saunders of the U.S. Department of Energy's Office of Health and Environmental Research were instrumental in providing resources and support for implementing one of the largest ocean margin research and field programs ever conducted, and we thank them both. This work was funded by the Ocean Margins Program of the Department of Energy and the Chemical Oceanography Program of the National Science Foundation.

\section{References}

Alperin, M. J., C. S. Martens, D. B. Albert, I. B. Suayah, L. K. Benninger, N. E. Blair, and R. A Jahnke, Benthic fluxes and pore water concentration profiles of dissolved organic carbon in sediments from the North Carolina continental slope, Geochim. Cosmochim. Acta, 63, 427-488, 1999.

Anderson, R., G. Rowe, P. Kemp, S. Trumbore, and P. Biscaye, Carbon budget for the mid-slope depocenter of the Middle Atlantic Bight, Deep Sea Res., Part II, 41, 669-703, 1994.

Bates, N. R, and D. A. Hansell, A high resolution study of surface layer hydrographic and biogeochemical properties between Chesapeake Bay and Bermuda, Mar. Chem., 67, 1-16, 1999.

Bauer, J. E., and E. R. M. Druffel, Ocean margins as a significant source of organic matter to the open ocean, Nature, 392, 482-485, 1998.

Bauer, J. E., P. M. Wiliams, and E. R. M. Druffel, ${ }^{14} \mathrm{C}$ activity of dissolved organic carbon fractions in the North Central Pacific and Sargasso Sea, Nature, 357, 667-670, 1992a.

Bauer, J. E., P. M. Williams, and E. R. M. Druffel, Recovery of sub-milligram quantities of carbon dioxide from gas streams by molecular sieve for subsequent determination of isotopic natural abundances ${ }^{13} \mathrm{C}$ and $\left.{ }^{14} \mathrm{C}\right)$, Anal. Chem. 64, 824-827, $1992 \mathrm{~b}$.

Bauer, J. E., M. L. Occelli, P. M. Williams, and P. C. McCaslin, Heterogeneous catalyst structure and function: Review and implications for the analysis of dissolved organic carbon and nitrogen in natural waters, Mar. Chem., 41, 75-89, 1993.

Bauer, J. E., C. E. Reimers, E. R. M. Druffel, and P. M. Williams, Isotopic constraints on carbon exchanges between deep ocean sediments and seawater, Nature, 373, 686-689, 1995.

Bauer, J. E., E. R. M. Druffel, P. M. Williams, D. M. Wolgast, and S. Griffin, Temporal variability in dissolved organic carbon and radiocarbon in the eastern North Pacific Ocean, J. Geophys. Res., 103, 2867-2881, 1998. 
Bianchi, T. S., J. E. Bauer, E. R. M. Druffel, and C. D. Lambert, Pyrophaeophorbide- $a$ as a tracer of suspended particulate organic matter from the NE Pacific continental margin, Deep Sea Res., Part II, 45, 715-732, 1998.

Biscaye, P., C. Flagg, and P. Falkowski, The shelf edge exchange processes experiment, SEEP-II: An introduction to hypotheses, results and conclusions, Deep Sea Res., Part II, 41, 231-252, 1994.

Blair, N. E., G. P. Plaia, S. E. Boehme, D. J. DeMaster, and L. A. Levin, The remineralization of organic carbon on the North Carolina continental slope, Deep Sea Res., Part II, 41, 755-766, 1994.

Boehm, P. D., and A. G. Requejo, Overview of the recent sediment hydrocarbon geochemistry of Atlantic and Gulf coast outer continental shelf environments, Estuarine Coastal Shelf Sci., 23, 29-58, 1986.

Boicourt, W. C., Circulation in the Chesapeake Bay entrance region: Estuary-shelf interaction, in Chesapeake Bay Plume Study: Superflux 1980, edited by J. W. Campbell and J. P. Thomas, NASA Conf. Publ., 2188, 61 78, 1981.

Burdige, D. J., and K. G. Gardner, Molecular weight distribution of dissolved organic carbon in marine sediment pore waters, Mar. Chem., 62 , $45-64,1998$.

Burdige, D. J., W. M. Burrelson, K. H. Coale, J. McManus, and K. S. Johnson, Fluxes of dissolved organic carbon from California continental margin sediments, Geochim. Cosmochim. Acta, 63, 1507-1515, 1999.

Chapman, D. C., and R. C. Beardsley, On the origin of shelf water in the Middle Atlantic Bight, J. Phys. Oceanogr., 19, 384-391, 1989.

Chen, R. F., B. Fry, C. S. Hopkinson, D. J. Repeta, and E. T. Peltzer, Dissolved organic carbon on Georges Bank, Cont. Shelf Res., 16, 409420, 1996.

Chesselet, R., M. Fontugne, P. Buat-Menard, U. Ezat, and C. E. Lambert, The origin of particulate organic carbon in the marine atmosphere as indicated by its stable carbon isotopic composition, Geophys. Res. Lett., $8,345-348,1981$.

Churchill, J. H., The effect of commercial trawling on sediment resuspension and transport over the Middle Atlantic Bight continental shelf, Cont. Shelf. Res., 9, 841-865, 1989.

Churchill, J. H., and T. J. Berger, Transport of Middle Atlantic Bight shelf water to the Gulf Stream near Cape Hatteras, J. Geophys. Res., 103, 30,605-30,621, 1998.

Churchill, J. H., E. R. Levine, D. N. Connors, and P. C. Cornillon, Mixing of shelf, slope and Gulf Stream water over the continental slope of the Middle Atlantic Bight, Deep Sea Res., 40, 1063-1085, 1993.

Csanady, G. T., J. H. Churchill, and B. Butman, Near-bottom currents over the continental slope in the mid-Atlantic Bight, Cont. Shelf Res., 8, 653672,1988 .

del Giorgia, P. A., J. J. Cole, and A. Cimbleris, Respiration rates in bacteria exceed phytoplankton production in unproductive aquatic systems, Nature, 385, 148-150, 1997.

Druffel, E. R. M., and P. M. Williams, Identification of a deep source of particulate organic carbon using bomb ${ }^{14} \mathrm{C}$, Nature, 347, 172-174, 1990.

Druffel, E. R. M., P. M. Williams, J. E. Bauer, and J. Ertel, Cycling of dissolved and particulate organic matter in the open ocean, J. Geophys. Res., 97, 15,539-15,659, 1992.

Druffel, E. R. M., J. E. Bauer, P. M. Williams, S. Griffin, and D. M. Wolgast, Seasonal variability of particulate organic radiocarbon in the northeast Pacific Ocean, J. Geophys. Res., 101, 20,54320,552, 1996.

Druffel, E. R. M., S. Griffin, J. E. Bauer, D. M. Wolgast, and X.-C. Wang, Distribution of particulate organic carbon and radiocarbon in the water column from the upper slope to the abyssal northeastern Pacific Ocean, Deep Sea Res., Part II, 45, 667-687, 1998.

Duarte, C. M., and S. Agusti, The $\mathrm{CO}_{2}$ balance of unproductive aquatic ecosystems, Science, 281, 234-236, 1998.

Duarte, C. M., S. Agusti, P. A. del Giorgio, and J. J. Cole, Regional carbon imbalance in the oceans, Science, 284, 1735, 1999.

Eppley, R. W., New production: History, methods, problems, in Productivity of the Ocean: Present and Past, edited by W. H. Berger, V. S. Smetacek, and G. Wefer, pp. 85-97, John Wiley, New York, 1989.

Eppley, R. W., and B. J. Peterson, Particulate organic matter flux and planktonic new production in the deep ocean, Nature, 282, 677-680, 1979.

Falkowski, P. G., C. N. Flagg, G. T. Rowe, S. L. Smith, T. E. Whitledge, and C. D. Wirick, The fate of a spring diatom bloom: Export or oxidation?, Cont. Shelf. Res., 8, 457-484, 1988.

Fischer, H. B., Mixing processes on the Atlantic continental shelf, Cape Cod to Cape Hatteras, Limnol. Oceanogr., 25, 114-125, 1980.

Fisher, T. R., J. D. Hagy, and E. Rochell-Newall, Dissolved and parti- culate organic carbon in Chesapeake Bay, Estuaries, 21, 215-219, 1998.

Ford, W. L., J. R. Longard, and R. E. Banks, On the nature, occurrence and origin of cold, low salinity water along the edge of the Gulf Stream, $J$. Mar. Res., 11, 281-293, 1952.

Fry, B., and E. B. Sherr, $\delta^{13} \mathrm{C}$ measurements as indicators of carbon flow in marine and freshwater ecosystems, Contrib. Mar. Sci., 27, 15-47, 1984.

Gagosian, R. B., and E. T. Peltzer, The importance of atmospheric input of terrestrial organic matter to deep sea sediments, Org. Geochem., 10, $661-669,1986$.

Gawarkiewicz, G., C. A. Linder, J. F. Lunch, A. E. Newhall, and J. J., Bisagni, A surface-trapped intrusion of slop water onto the continental shelf in the mid-Atlantic Bight, Geophys. Res. Lett., 23, 3763-3766, 1996.

Goni, M. A., K. C. Ruttenberg, and T. I. Eglinton, A reassessment of the sources and importance of land-derived organic matter in surface sediments from the Gulf of Mexico, Geochim. Cosmochim. Acta, 62, 3055$3075,1998$.

Guo, L., and P. H. Santschi, Sedimentary sources of old high molecular weight dissolved organic carbon from the ocean margin benthic nepheloid layer, Geochim. Cosmochim. Acta, 64, 651-660, 1999.

Guo, L., P. Santschi, L. Cifuentes, S. Trumbore, and J. Southon, Cycling of high-molecular-weight dissolved organic matter in the Middle Atlantic Bight as revealed by carbon isotopic (C-13 and C-14) signatures, Limnol. Oceanogr., 41, 1242-1252, 1996.

Hedges, J. I., Global biogeochemical cycles: Progress and problems, Mar: Chem., 39, 67-93, 1992.

Hedges, J. I., and R. G. Keil, Organic geochemical perspectives on estuarine processes: Sorption reactions and consequences, Mar. Chem., 65, 55$65,1999$.

Hedges, J. I., J. R. Ertel, P. D. Quay, P. M. Grootes, J. Richey, A. H. Devol, and G. W. Farwell, Organic carbon-14 in the Amazon River system, Science, 231, 1129-1131, 1986.

Hedges, J. I., B. A. Bergamaschi, and R. Benner, Comparative analyses of DOC and DON in natural waters, Mar. Chem., 41, 121-134, 1993.

Hedges, J. I., R. G. Keil, and R. Benner, What happens to terrestrial organic matter in the ocean?, Org. Geochem., 27, 195-212, 1997.

Hickey, B. M., Transport due to freshwater discharge into the coastal ocean, in Coastal Ocean Processes (CoOP): Transport and Transformation Processes Over Continental Shelves With Substantial Freshwater Inflows, CoOP Rep. 7 (UMCES TS-237-00), pp. 47-68, Univ. of Md. Cent. for Environ. Stud., Cambridge, 2000.

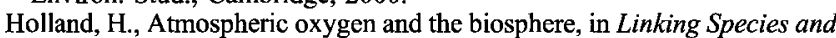
Ecosystems, edited by C. G. Jones and J. H. Lawton, Chapman and Hall, New York, 1995.

Honda, M. C., M. Kusakabe, S. Nakabayashi, and M. Katagiri, Radiocarbon of sediment trap samples from the Okinawa trough: Lateral transport of ${ }^{14} \mathrm{C}$-poor sediment from the continental slope, Mar. Chem., 68, $231-$ $247,2000$.

Hopkinson, C. S., B. Fry, and A. Nolin, Stoichiometry of dissolved organic matter dynamics on the continental shelf of the northeastern U.S.A., Cont. Shelf Res., 17, 473-489, 1997.

Houghton, R. W., D. B. Olson, and P. J. Celone, Observations of an anticyclonic eddy near the continental shelfbreak south of New England, $J$. Phys. Oceanogr, 16, 60-71, 1986.

Houghton, R. W., C. N. Flagg, and L. J. Pietrafesa, Shelf-slope water frontal structure, motion and eddy heat flux in the southern Middle Atlantic Bight, Deep Sea Res. Part II, 41, 273-306, 1994.

Hung, J. J., C.S. Lin, G. W. Hung, and Y. C. Chung, Lateral transport of lithogenic particles from the continental margin of the southern East China Sea, Estuarine Coastal Shelf Sci., 49, 483-499, 1999.

Iselin, C. O., A study of the circulation of the western North Atlantic, $P$. Phys. Oceanogr. Meteorol., 4, 1-101, 1936.

Jenkins, W. J., Tritium-Helium dating in the Sargasso Sea: A measurement of oxygen utilization rates, Science, 196, 291-292, 1977.

Joyce, T. M., J. K. Bishop, and O. B. Brown, Observations of offshore shelf-water transport induced by a warm-core ring, Deep Sea Res., 39(S1), 97-113, 1992.

Kashgarian, M., and N. Tanaka, Antarctic intermediate water intrusion into South Atlantic Bight shelf waters, Cont. Shelf. Res., 11, 197-201, 1991.

Keil, R. G., E. Tsamakis, C. B. Fuh, J. C. Giddings, and J. I Hedges, Mineralogical and textural controls on the organic composition of coastal marine sediments: Hydrodynamic separation using SPLITT- fractionation, Geochim. Cosmochim. Acta, 58, 879-893, 1994a.

Keil, R. G., D. B. Montlucon, F. G. Prahl, and J. I. Hedges, Sorptive preservation of labile organic matter in marine sediments, Nature, 370 , $549-552,1994 b$. 
Kiel, R. G., L. M. Mayer, P. D. Quay, J. E. Richey, and J. I. Hedges, Loss of organic matter from riverine particles in deltas, Geochim. Cosmochim. Acta, 61, 1507-1511, 1997.

Kwak, T. J., and J. B. Zedler, Food web analysis of southern California coastal wetlands using multiple stable isotopes, Oecologia, 110, 262$277,1997$.

Ledwell, J. R., A. J. Watson, and C. S. Law, Evidence for slow mixing across the pycnocline from an open-ocean tracer-release experiment, Nature, 364, 701-703, 1993.

Loder, J. W., B. Petrie, and G. Gawarkiewicz, The coastal ocean off northeastern North America: A large-scale view, in The Sea, Vol. 11, The Global Coastal Ocean, edited by K. H. Brink and A. R. Anderson, pp. 105-133, John Wiley, New York, 1998.

Malone, T. C., and H. W. Ducklow, Microbial biomass in the coastal plume of Chesapeake Bay: Phytoplankton-bacterioplankton relationships, Limnol. Oceanogr, 35, 296-312, 1990.

Mantoura, R. F. C., and E. M. S. Woodward, Conservative behaviour of riverine dissolved organic carbon in the Severn Estuary: chemical and geochemical implications, Geochim. Cosmochim. Acta, 47, 1293-1309, 1983.

Mayer, L., Surface area control of organic carbon accumulation in continental shelf sediments, Geochim. Cosmochim. Acta, 58, 1271-1284, 1994.

McNichol, A. P., G. A. Jones, D. L. Hutton, A. R. Gagnon, and R. M. Keu, The rapid preparation of seawater $\mathrm{\Sigma CO}_{2}$ for radiocarbon analysis at the National Ocean Sciences AMS facility, Radiocarbon, 36, 237-246, 1994.

Meade, R. H., P. L. Sachs, F. T. Manheim, J. C. Hathaway, and D. W. Spencer, Sources of suspended matter in waters of the Middle Atlantic Bight, J. Sed. Petrol., 45, 171-188, 1975.

Meyers-Schulte, K., and J. I. Hedges, Molecular evidence for a terrestrial component of organic matter dissolved in ocean water, Nature, 321, 6163, 1986.

Michener, R. H., and D. M. Schell, Stable isotope ratios as tracers in marine aquatic food webs, in Stable Isotopes in Ecology and Environmental Science, edited by K. Lajtha and R. H. Michener, pp. 138-157, Blackwell Scientific, Malden, Mass., 1994.

Mitra, S., T. S. Bianchi, L. Guo, and P. H. Santschi, Terrestrially derived dissolved organic matter in the Chesapeake Bay and Middle Atlantic Bight, Geochim. Cosmochim. Acta, 64, 3547-3557, 2000.

Mopper, K., X. Zhou, R. J. Kieber, D. J. Kieber, R. J. Sikorski, and R. D. Jones, Photochemical degradation of dissolved organic carbon and its impact on the oceanic carbon cycle, Nature, 353, 60-62, 1991.

Moran, M. A., L. R. Pomeroy, E. S. Sheppard, L. P. Atkinson, and R. E. Hodson, Distribution of terrestrially derived dissolved organic matter on the southeastern U.S. continental shelf, Limnol. Oceanogr., 36, 1134$1149,1991$.

Mountain, D. G., The volume of Shelf Water in the Middle Atlantic Bight: Seasonal and interannual variability, 1977-1987, Cont. Shelf. Res., 11, $251-267,1991$.

Mulholland, P. J., and J. A. Watts, Transport of organic carbon to the oceans by rivers of North America: a synthesis of existing data, Tellus, 34, 176$186,1982$.

Nittrouer, C. A., and L. D. Wright, Transport of particles across continental shelves, Rev. Geophys., 32, 85-113, 1994.

Opsahl, S., and R. Benner, Distribution and cycling of terrigenous dissolved organic matter in the ocean, Nature, 386, 480-482, 1997.

Opsahl, S., R. Benner, and R. Amon, Major flux of terrigenous dissolved organic matter through the Arctic Ocean, Limnol. Oceanogr., 44, 20172023,1999

Ostlund, H. G., and C. G. H. Rooth, The North Atlantic tritium and radiocarbon transients 1972-1983, J. Geophys. Res., 95, 20,147-20,175, 1990.

Peltzer, E., Shipboard measurement of dissolved organic carbon, paper presented at ACS Symposium Measurement and Reactivity of Organic Materials in Natural Waters, Am. Chem. Soc., San Diego, Calif., 1994.

Peterson, B. J., and R. W. Howarth, Sulfur, carbon and nitrogen isotopes used to trace organic matter flow in the salt-marsh estuaries of Sapelo Island, Georgia, Limnol. Oceanogr., 32, 1195-1213, 1987.

Pietrafesa, L. J., J. M. Morrison, M. P McCann, J. Churchill, E. Bohm, and R. W. Houghton, Water mass linkages between the Middle and South Atlantic Bights, Deep Sea Res., Part II, 41, 365-389, 1994.

Raymond, P. A., Carbon cycling in the York River estuary: An isotopic and mass balance approach using natural ${ }^{14} \mathrm{C}$ and ${ }^{13} \mathrm{C}$ isotopes, Ph.D. dissertation, School of Mar. Sci. NIMS, College of William and Mary, Williamsburg, Va., 1999.
Raymond, P. A., and J. E. Bauer, Bacterial utilization and transport of labile DOC in the York River estuary and implications for its export to the coastal ocean, Aquat. Microb. Ecol, 22, 1-12, 2000.

Raymond, P. A., and J. E. Bauer, DOC cycling in a temperate estuary: A mass balance approach using natural ${ }^{14} \mathrm{C}$ and ${ }^{13} \mathrm{C}$, Limnol. Oceanogr., 46 , 655-667, 2001a.

Raymond, P. A., and J. E. Bauer, Riverine export of aged terrestrial organic matter to the North Atlantic Ocean, Nature, 409, 497-500, 2001b.

Richey, J. E., J. I. Hedges, A. H. Devol, P. D. Quay, R. Victoria, L Martinelli, and B. C. Forsberg, Biogeochemistry of carbon in the Amazon River, Limnol. Oceanogr., 35, 352-371, 1990.

Ruzecki, E. P., Temporal and spatial variations of the Chesapeake Bay plume, in Chesapeake Bay Plume Study: Superflux 1980, edited by J. W. Campbell and J. P. Thomas, NASA Conf. Publ., 2188, 111-130, 1981.

Schubel, J. R., and D. W. Pritchard, Responses of upper Chesapeake Bay to variations in discharge of the Susquehanna River, Estuaries, 9, 236-249, 1986.

Sharp, J. H., R. Benner, L. Bennett, C. A. Carlson, R. Dow, and S. E. Fitzwater, A re-evaluation of high-temperature combustion and chemical oxidation measurements of dissolved organic carbon in seawater, Limnol. Oceanogr., 38, 1774-1782, 1993.

Shaw, P.-T., L. J. Pietrafesa, C. N. Flagg, R. W. Houghton, and K.-H. Su, Low-frequency oscillations on the outer shelf in the southern Mid-Atlantic Bight, Deep Sea Res., Part II, 41, 253-271, 1994.

Sherrell, R., M. Field, and Y. Gao, Temporal variability of suspended mass and composition in the NE Pacific water column: Relationships to sinking flux and lateral advection, Deep Sea Res., Part II, 45, 733-761, 1998.

Small, L. F. (Ed.), California Basin studies: Physical, geological, chemical and biological attributes, Prog. Oceanogr., 30, 1-392, 1992.

Smith, S. V., and J. T. Hollibaugh, Coastal metabolism and the oceanic organic carbon balance, Rev. Geophys., 31, 75-89, 1993.

Smith, S. V., and F. T. MacKenzie, The ocean s a net heterotrophic system: Implications from the carbon biogeochemical cycle, Global Biogeochem. Cycles, $1,187-198,1987$.

Sofer, Z., Preparation of carbon dioxide for stable carbon isotope analysis of petroleum, Anal. Chem., 52, 1389-1391, 1980.

Spiker, E. C., and M. Rubin, Petroleum pollutants in surface and groundwater as indicated by the carbon-14 activity of dissolved organic carbon, Science, 187, 61-64, 1975.

Spitzy, A., and V. Ittekot, Dissolved and particulate organic matter in rivers, in Ocean Margin Processes in Global Change, edited R. F. C. Mantoura, J.-M. Martinm, and R. Wollast, pp. 5-17, John Wiley, New York, 1991.

Tanaka, N., M. C. Monaghan, and K. K. Turekian, $\Delta^{14} \mathrm{C}$ balance for the Gulf of Maine, Long Island Sound and the northern Middle Atlantic Bight: Evidence for the extent of the Antarctic intermediate water intrusion, J. Mar. Res., 48, 75-87, 1990.

Tanaka, N., K. K. Turekian, and D. M. Rye, The radiocarbon, $\delta^{13} \mathrm{C},{ }^{210} \mathrm{~Pb}$, and ${ }^{137} \mathrm{Cs}$ record in box cores from the continental margin of the Middle Atlantic Bight, Am. J. Sci., 291, 90-105, 1991.

Trumbore, S. E., S. L. Schiff, R. Aravena, and R. Elgood, Sources and transformation of dissolved organic carbon in the Harp Lake forested catchment - The role of soils, Radiocarbon, 34, 626-635, 1992.

Valiela, I., Marine Ecological Processes, 686 pp., Springer-Verlag, New York, 1995.

Velinsky, D. J., T. L. Wade, and G. T. F. Wong, Atmospheric deposition of organic carbon to Chesapeake Bay, Atmos. Environ., 20, 941-947, 1986.

Vlahos, P., A. Vetrano, T. S. Hopkins, and R. F. Chen, Fluxes of dissolved organic carbon off the Middle Atlantic Bight, Eos Trans. $A G U, 79,183$, 1998.

Vogel, J., D. Nelson, and J. Southon, ${ }^{14} \mathrm{C}$ background levels in an accelerator mass spectrometry system, Radiocarbon, 29, 323-333, 1987.

Walsh, J. J., On the Nature of Continental Shelves, 520 pp., Academic, San Diego, Calif., 1988.

Walsh, J. J., How much shelf production reaches the open ocean?, in Productivity of the Ocean: Present and Past, edited by W. H. Berger, V. S. Smetacek, and G. Wefer, pp. 175-191, John Wiley, New York, 1989.

Walsh, J. J., Importance of continental margins in the marine biogeochemical cycling of carbon and nitrogen, Nature, 350, 53-55, 1991.

Walsh, J. J., P. E. Biscaye, and G. T. Csanady, The 1983-1984 Shelf Edge Exchange Program (SEEP) - I experiment: Hypotheses and highlights, Cont. Shelf Res., 8, 435-456, 1988.

Wang, X.-C., and C. Lee, Adsorption and desorption of aliphatic amines, 
amino acids and acetate by clay minerals and marine sediments, Mar. Chem., 44, 1-23, 1993.

Willey, J. D., R. J. Kieber, M. S. Eyman, and G. B. Avery, Rainwater dissolved organic carbon: Concentrations and global flux, Global Biogeochem. Cycles, 14, 139-148, 2000.

Williams, P. M., and E. R. M. Druffel, Radiocarbon in dissolved organic matter in the central North Pacific Ocean, Nature, 330, 246-248, 1987.

Williams, P. M., K. J. Robertson, A. Souter, S. M. Griffin, and E. R. M. Druffel, Isotopic signatures $\left({ }^{14} \mathrm{C},{ }^{13} \mathrm{C},{ }^{15} \mathrm{~N}\right)$ as tracers of sources and cycling of DOC and POC in the Santa Monica Basin, California, Prog. Oceanogr., 30, 253-290, 1992.

Williams, P. M., J. E. Bauer, K. R. Robertson, D. M. Wolgast, and M. L. Occelli, Report on DOC and DON measurements at Scripps Institution of Oceanography, 1988-1991, Mar. Chem., 41, 271-281, 1993.

Wollast, R., Evaluation and comparison of the global carbon cycles in the coastal zone and in the open ocean, in The Sea, Vol. 10, The Global Coastal Ocean, edited by K. H. Brink and A. R. Anderson, pp. 213-252, John Wiley, New York, 1998.
Wright, L. D., and C. C. A. Nittrouer, Dispersal of river sediments in coastal seas, Estuaries, 18, 494-508, 1995.

Zafiriou, O. C., R. B. Gagosian, E. T. Peltzer, and J. B. Alford, Air-to-sea fluxes of lipids at Enewetak Atoll, J. Geophys. Res., 90, 2409-2423, 1985.

J. E. Bauer, School of Marine Science, College of William and Mary, Gloucester Point, VA 23062, USA. (bauer@vims.edu)

E. R. M. Druffel, and S. Griffin, Department of Earth System Science, University of California, Irvine, CA 92697, USA.

D. M. Wolgast, Marine Research Division, Scripps Institution of Oceanography, University of California, La Jolla, CA 92093, USA.

(Received June 14, 2000; revised November 20, 2000; accepted December 20, 2000.) 